\title{
DEFINING THE FIELD OF IMMIGRATION STUDIES: A PRELIMINARY STUDY OF RESEARCH CONTRIBUTIONS
}

\author{
by \\ Olena Ingerova, BA, York University, 2006 \\ A Major Research Paper \\ presented to Ryerson University \\ in partial fulfillment of the requirements for the degree of \\ Master of Arts \\ in the Program of \\ Immigration and Settlement Studies
}

Toronto, Ontario, Canada, 2008

(C) Olena Ingerova 2008 


\section{Author's Declaration}

I hereby declare that I am the sole author of this major research paper.

I authorize Ryerson University to lend this paper to other institutions or individuals for the purpose of scholarly research.

Signature

I further authorize Ryerson University to reproduce this paper by photocopying or by other means, in total or in part, at the request of other institutions or individuals for the purpose of scholarly research.

Signature 


\title{
DEFINING THE FIELD OF IIMMIGRATION STUDIES: A PRELIMINARY STUDY OF RESEARCH CONTRIBUTIONS
}

(C) Olena Ingerova, 2008

\author{
Master of Arts \\ Immigration and Settlement Studies \\ Ryerson University
}

\begin{abstract}
This is a study that in a preliminary way explores the boundaries of immigration as a field of study. It does so at two scales - the national and the local - by examining a sample of articles published in the Journal of International Migration and Integration and Michael Doucet's Bibliography on Immigration and Settlement in the Toronto Area, Third Edition. The implications of findings are then discussed in the light of concepts such as multidisciplinarity, authorship, and knowledge production.
\end{abstract}

Key words: immigration research; discipline; multidisciplinary; authorship 


\section{TABLE OF CONTENTS}

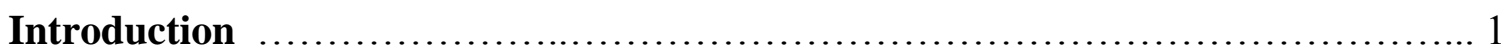

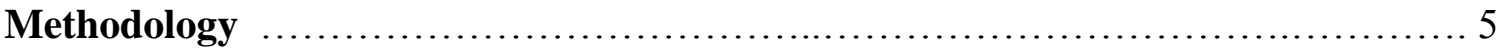

Journal of International Migration and Integration ............................ 9

Bibliography on Immigration and Settlement in the Toronto Area .............. 16

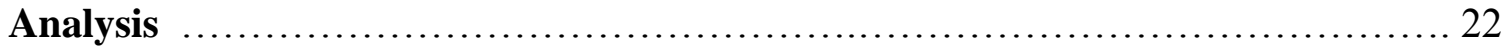

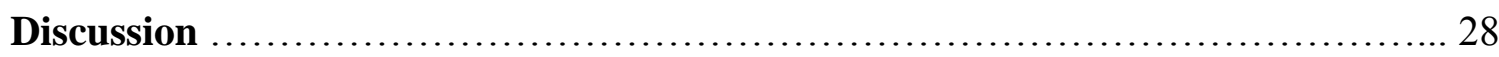

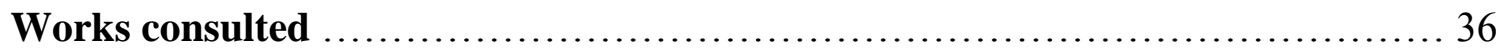

APPENDIX A - JIMI Sample............................................. 39

APPENDIX B - Bibliography Sample.................................. 46 


\section{LIST OF TABLES}

Table 1 - Doucet Bibliography, Section A, Article Selection ........................ 7

Table 2 - JIMI, Solo and Joint Publications by Academic Discipline ............... 11

Table 3 - JIMI, Article Distribution by Topic .............................. 14

Table 4 - Doucet Bibliography, Solo and Joint Publications by Academic Discipline ...17

Table 5 - Doucet Bibliography, Article Distribution by Topic ................... 20

Table 6 - JIMI and Doucet, Top 12 Contributing Disciplines $\ldots \ldots \ldots \ldots \ldots \ldots \ldots \ldots . \ldots 22$

Table 7 - JIMI and Dooucet, Top Five Contributing Disciplines in Rank Order ....... 24 


\section{INTRODUCTION}

Recent years have seen a $\mathrm{m}$ assive growth in writing ab out imm igration and settlement. This is symptom atic of a trem endous upsurge in acad emic writing about immigration. W hile imm igration studies does not exist as an acad emic discipline in Canadian universities, it is $m$ ost certainly a distinct field of study, as evidenced by the existence of scholarly publications, university programs, and conferences dedicated to he study of immigration. In addition to being a newly expanded field of study, the literature on immigration is both multidis ciplinary and multisectoral in nature. People write about immigration from different organizational platforms, including universities, governm ent, and the non-profit sector. Within each organizational platform further subdivisions occur. Scholars an $\mathrm{d}$ resear chers af filiated with unive rsities con tribute f rom a $\mathrm{m}$ ultitude of academic disciplines; governm ent contribution s range from $\mathrm{m}$ unicipal Task Forces to intergovernmental organizations; the non-profit sector ranges in focus from research to service to advocacy. This $\mathrm{m}$ ultidisciplinary and $\mathrm{m}$ ultisectoral natu re of immigration research raises some interesting questions hitherto unexplored. For example, what are the boundaries of immigration as a field of study? Who is contributing to this field? D oes one's disciplinary or organizational setting infl uence research and/or topics of res earch? In what way can this occur? What implications does this have for immigration research?

Multidisciplinary programs emerged in response to the dem ands arising from the larger political clim ate of anti-imperia lism, civil rights, anti-racism , and women's movements that saw previously m arginalized groups gain access to university campuses. These racialized, gendered, and classed groups demanded changes to the curriculum that 
reflected th eir pres ence in the academ y a nd explored and celebrated their diverse histories, w hich were not plausible in the confines of the trad itional discip lines. The emergence of $\mathrm{m}$ ultidisciplinary pro grams as a result expanded the field of inquiry and reconfigured the contours of knowledge and m ethods of knowledge production (Katz, 2001)

As multidisciplinary programs gained a de gree of relative institutional com fort, they began to establish their own boundaries and define them selves $m$ ore clearly. Complicating the picture is the fact that multidisciplinary fields of study have grown while the disciplines themselves have not, resu lting at the sam e time in the blurring and the expansion of boundaries (Katz, 2001) . The definition of these boundaries is becoming more im portant in the present ac ademic clim ate of budgetary $r$ estraints, cutbacks, and shrinkages that see the e mergence of a c onsumerist model of higher education that em phasizes the m arketing of graduates and knowle dge production (Katz, 2001; Archer, 2008). According to Katz (2001), hi s has led to a stricter policing of the borders between disciplines both on the scholarly and the administrative side. Considering that $\mathrm{m}$ ost multidis ciplinary prog rams are run by $\mathrm{f}$ aculty who have prim ary appointments in particular disciplines and th at most departm ents prefer to hire people trained specifically in th eir disciplines (Katz, 2001), this newfound redefinition of disciplinary boundaries can carry interesting implications for multidisciplinary programs.

Immigration is a particularly in teresting case because, by virtue of being a new field of study in additio $\mathrm{n}$ to being a $\mathrm{m}$ ultidisciplinary one, its boundaries have not yet been established. In order to gain institutional stability, the field needs to be more clearly defined. What disciplines does it draw on? W hat binds thes e dis ciplines toge ther? Are 
there any differences a mong the $\mathrm{m}$ ember di sciplines with respect to theoretical frameworks and philosophical a pproaches? How does autho rship affect research? Is it a multidisciplinary field that borrows from other disciplines or an interdisciplinary one that truly integ rates exis ting discip lines to define appropriate objects of inquiry, methodologies, interpretation and analysis?

In order to answer the questions surr ounding the evolution of $\mathrm{i}$ mmigration as a field of study, we must first de fine it. This is a study that in a prelim inary way explores the boundaries of imm igration as a field of study. Specifically, I seek to answer the following four questions:

(1) In the m ultidisciplinary field tha $t$ is im migration studies, which disciplines are contributing?

(2) What topics are getting the most attention?

(3) Is there a link between an author's discipline and research focus?

(4) Is immigration a multidisciplinary field or an interdisciplinary one?

This study takes place in a Canadian c ontext and it does so on two scales: the national and the local. First of all, I a $\mathrm{m}$ in terested in Canada because immigration is a national project. Second, I am interested in To ronto becaus e most immigrants settle in cities and Toronto is by far the largest recipient of newcomers. As a proxy of immigration research, I have taken two publications to captu re the two scales of my exploration: the Journal of International Migration and Integration (JIMI) to represent national research 
and Michael Doucet's latest Bibliography on Immigration and Settlement in the Toronto Area, Third Edition (henceforth Bibliography).

JIMI is a product of the International Metropolis Project and provides a "new multidisciplinary forum for the study of hum an migration and integration". It emphasizes multidisciplinary, inte rdisciplinary, com parative, and po licy-relevant $r$ esearch. At the same time, it is an independent, peer-revie wed and "auton omous academic journal th at advocates scholarship independent of the poli tical or policy views of its in stitutional sponsors." It covers a wide range of topi cs concerning both immigration and integration, as well as pertaining to ethnocultural diversity (Abu-Laban and Vermeulen, 2000). While JIMI in in ternational in scope, it is $\mathrm{f}$ irst and foremost a Canadian publication and is cosponsored by the Metropolis P roject, Citi zenship and Imm igration Canada, the Social Sciences and Hum anities Res earch Council of Canada, the Un iversity of Alberta, the University of Saskatchewa n, the Atlantic (A MA), Mont real (IM), Vancouver (RIIM), Toronto (CERIS) and Edm onton (PCERII) Me tropolis Centres, th e Gouvernem ent du Québec, Ministère des Relations avec les citoye ns et de l' Immigration, and a consortium of Canadian federal government departments.

Michael Do ucet ha s be en com piling sources of immigration rese arch concern ing Toronto since 1999, each updated edition reflec ting the enorm ous grow th in literature. The original 1999 version contained 554 entrie s, which grew to 946 in the Second Edition. His latest Bibliography contains 3,428 entries and provides a listing of books, monographs, research reports, graduate thes es, book chapters, and journal articles that deal with immigration and settlement in the Toronto area. 


\section{METHODOLOGY}

The two publications chos en for analysis, JIMI and Bibliography, were treated as sources of data. Select articles from each one were profiled as data un its. The authors of each work were iden tified and clas sified with respect to th eir organization platform. The three identified platforms were academ ic, non-governmental organizations (NGOs), and government. Each of the three platform s was then further subdivided into disciplinary and sec toral affiliations. Academ ic sources were tabu lated accord ing to the au thors' affiliations as indicated in each respective pub lication, NGO sources with respect to mandate (research, advocacy, or service based), and governm ent sources with respect to departments. In the cas e of joint publicati ons, each author was assigned equal weight, resulting in more authors than articles in the analysis. Cross-organizational collaborations were considered. Finally, research topics were analyzed to determ ine if there existed a link between authors' affiliation and the topics being researched.

The first issue of JIMI appeared in wi nter of 2000. Currently, nine volum es have been published. However, since the year 2008 is not yet complete, Volum e No. 9 is not included in this an alysis to avoid co mpromising the re sults with an in complete sample. All th e a rticles were $\mathrm{c}$ ompiled in to a table in the orde $r$ tha $t$ th ey appeared in the

publication's table of contents, beginning with th e f irst issu e and con tinuing chronologically until the last issue of Volume No. 8. T his list yielded 182 articles covering the period from 2000-2007. Due to the operational constraints of this study, this number was cut in half by random ly selecting every other article beginning with the first article on the list. It should be noted the JIMI did not specify its editorial policy about the 
ordering of articles on the li st. As such, it was presum ed that this ordering was random and will not affect the s election process of articles for the present study. The resulting 91 articles were then profiled with resp ect to authorship. Each author's organizational and disciplinary affiliation was noted an $\mathrm{d}$ tabulated. This inf ormation was derived $\mathrm{f}$ rom the Contributor's Notes s ection of each issue. Where insufficient information was provided, an additional search was perform ed on the in ternet using univers ity and organization websites to dete rmine author cred entials. W here bo th ap proaches f ailed to $\mathrm{p}$ roduce sufficient information, the author was classified as unidentified.

Michael Doucet's Bibliography consists of three parts: (A) studies on immigration and settlement in the Toronto area, (B) studi es of particular groups of comm unities, and (C) fictional accounts of the imm igrant experience in Toronto. In total, the Bibliography contains 3,428 entries, some of which are duplicated under different headings. Section A numbers $2,099^{1}$ sources, section B has 1,169 , and section $C$ has 161 . Given the great discrepancy in num bers from JIMI, the fo llowing approach was taken to obtain a comparable sample: First of all, Sec tion C was not inc luded in the an alysis because the focus of thi s study is immigration resear ch. Second, only the works published between the years of 2000 and 2007 were included in th e analysis to align the Doucet analysis with the time period ex amined in JIMI. Th ird, since Section A contains approxim ately double the number of sources found in Section B, two works from Section A were taken for each work taken from Section B. Both section A and section B are divided into subsections, which contain unequal num bers of sources. To ensure an accurate representative sample, the number of articles taken from each section was proportional to

\footnotetext{
${ }^{1}$ Michael Doucet identifies 2,098 entries in this section. However, two separate counts have been performed and the number 2,099 will be used for all further calculations.
} 
the number of sources containe $d$ in each section. Finally, s ince some of the works were duplicated under different headings, this problem was addressed in the following manner: articles were selected random ly from each section in the o rder in which subheadings appeared in the bibliog raphy, starting with the first article under each subheading and following the calculations detailed in Table 1 . Where the article thus selected had already been chosen from a different subsection, th e very next article on the list was chosen instead. It should be noted th at articles were sorted alphabetically by author, not chronologically, in order to avoid overrepr esentation of the year 2000, which would occur in cases where only one article was chosen from a particular subsection. The chosen articles were then interfiled and profiled in the same way as described for JIMI.

The particular selection pro cess for articles fro $\mathrm{m}$ Section A was a little dif ferent from that for Section B. Section A contains $13^{2}$ headings, numbering 899 eligible articles with a pub lication date between 2000 and 2007. In to tal, 60 artic les were se lected from this section using the calculations process detailed in Table 1 below.

Table 1 - Doucet Bibliography, Section A, Article Selection

\begin{tabular}{|l|c|c|c|}
\hline Section A subheading & $\begin{array}{l}\text { \# of eligible } \\
\text { articles }\end{array}$ & \# of articles chosen & Order of selection \\
\hline $\begin{array}{l}\text { General Works, Pan- } \\
\text { Canadian Studies, and } \\
\text { Collections }\end{array}$ & 17 & 1 & First articles on the list \\
\hline $\begin{array}{l}\text { Guidebooks, } \\
\text { Bibliographies, and } \\
\text { Directories }\end{array}$ & 3 & 1 & First article on the list \\
\hline $\begin{array}{l}\text { Ethnic Neighbourhoods } \\
\text { and Residential } \\
\text { Segregation Studies }\end{array}$ & 644 & & $\begin{array}{c}\text { Every } 18^{\text {th }} \text { article } \\
(\# \# 1,19,37,55)\end{array}$ \\
\hline $\begin{array}{l}\text { Housing Experiences and } \\
\text { Issues for Immigrants and } \\
\text { Refugees }\end{array}$ & 413 & & $\begin{array}{c}\text { Every } 18^{\text {th }} \text { article } \\
(\# \# 1,19,37)\end{array}$ \\
\hline $\begin{array}{l}\text { Labour Market, } \\
\text { Entrepreneurship, } \\
\text { Economic Impacts, and }\end{array}$ & 1037 & & $\begin{array}{c}\text { Every } 17^{\text {th }} \text { one } \\
(\# \# 1,18,35,52,69,86, \\
103)\end{array}$ \\
\hline
\end{tabular}

\footnotetext{
${ }^{2}$ Michael Doucet identifies 12 headings in the table of contents. However, the bibliography itself contains one more section entitled "Demographic Profiles."
} 


\begin{tabular}{|c|c|c|c|}
\hline Socioeconomic Patterns & & & \\
\hline $\begin{array}{l}\text { Racism, Discrimination, } \\
\text { Race Relations, Police- } \\
\text { Community Relations, } \\
\text { and Related Studies }\end{array}$ & 503 & & $\begin{array}{l}\text { Every } 22^{\text {nd }} \text { article } \\
\quad(\# \# 1,23,45)\end{array}$ \\
\hline $\begin{array}{l}\text { Services and Agencies for } \\
\text { Immigrants and Refugees }\end{array}$ & 715 & & $\begin{array}{c}\text { Every } 17^{\text {th }} \text { article } \\
(\# \# 1,18,35,52,69)\end{array}$ \\
\hline $\begin{array}{l}\text { Education, Childhood, } \\
\text { Youth, Parenting, and } \\
\text { Related Works }\end{array}$ & 1208 & & $\begin{array}{c}\text { Every } 17^{\text {th }} \text { article } \\
(\# \# 1,18,35,52,69,86 \\
103,120)\end{array}$ \\
\hline $\begin{array}{l}\text { Socialization, Civic } \\
\text { Participation, Adaptation, } \\
\text { Identity, and Related } \\
\text { Works }\end{array}$ & 2771 & 8 & $\begin{array}{c}\text { Every } 16^{\text {th }} \text { article } \\
(\# \# 1,17,33,49,65,81 \\
97,113,129,145,161 \text {, } \\
177,193,209,225,241, \\
257,273)\end{array}$ \\
\hline $\begin{array}{l}\text { Immigrant and Refugee } \\
\text { Health }\end{array}$ & 624 & & $\begin{array}{l}\text { Every } 13^{\text {th }} \text { article } \\
(\# \# 1,14,27,40)\end{array}$ \\
\hline Immigration Policy & 56 & 4 & $\begin{array}{l}\text { Every } 17^{\text {th }} \text { article } \\
(\# \# 1,18,35,52)\end{array}$ \\
\hline $\begin{array}{l}\text { Miscellaneous General } \\
\text { Works }\end{array}$ & 14 & 1 & First article on the list \\
\hline Demographic Profiles & 11 & 1 & First article on the list \\
\hline Total & 899 & 60 ------ & \\
\hline
\end{tabular}

Section B contains 22 headings, 21 of which conta in eligible article s with a publication date between 2000 and 2007 for a total of 415 eligible artic les. Of these, 30 articles were chosen. $\mathrm{S}$ ince th ere were grea $\mathrm{t}$ discrepancies in the number of articles contained under each h eading - ranging from 2 to 77 - and only 30 articles were to be chosen, it was im possible to obtain a balanced sample using the sam e approach as was used in Section A due the large number of headings contained in this Section. In addition, articles were not grouped under headings by res earch topic like in Section A, but instead by a particular ethnic group to be studied. As a re sult, a different approach was undertaken. All the eligible articles from Section B were interfiled, sorted alphabetically, and then each $14^{\text {th }}$ article was rando mly selected starting with the first article on the list. Once again, if the article chosen in this way had already ap peared on the list of articles chosen previously, the very ne xt article on th e list was sele cted in stead. This way, the 
individual articles themselves were chosen randomly but in a way that as best as possible attempted to ensure a fairly equal dis tribution of articles according to the weight of each section. By selecting every $14^{\text {th }}$ ar ticle in th e alphabe tical order, th e chances th at the sections with a larger number of articles will be represented by a greater number of works were higher than for sections containing only a handful of entries, without the need to intentionally skip over certain sections.

Finally, the two sam ples derived from Section A and Section B were com bined and interfiled. The authors from each work we re extracted and profiled in the sam e way as for JIMI.

One major limitation of this study needs to be addressed at th is point. While I am sampling $50 \%$ of all JIMI articles, I am only sam pling $2.8 \%$ of research articles ${ }^{3}$ in Doucet's Bibliography (or 6.9\% of research articles published between 2000 and 2007). Sampling 50\% of the Bibliography articles was simply not feasible for this study. Instead, the same number of articles was chosen from Doucet as from JIMI to facilitate num erical comparisons between the two publications with respect to authors, partnerships, academic disciplines represented, and re search topics. W hile the desc ribed methodology allows at two scales to explore th e issue of discip linary and sectoral contribut ors to this $\mathrm{f}$ ield, I recognize that the fact that not all the articles were considered - particularly in Doucet's case, where only a small percen tage was sa mpled $-m$ ay result in a skewed sample. Nevertheless, I feel that $\mathrm{m} \quad \mathrm{y}$ chosen appr oach satisf ies the $\mathrm{m}$ odest goals o $\mathrm{f}$ this exploratory study in th e most practical way and the resu lting study can provide general direction for further research on this topic.

\footnotetext{
${ }^{3}$ This excludes Section $\mathrm{C}$ from calculations. The total number of research articles is 3,268. Of these, 1,314 were published between 2000 and 2007.
} 


\section{JOURNAL OF INTERNATIONAL MIGRATION AND INTEGRATION}

The selection process for JIMI y ielded a lis $t$ of 91 articles $f$ or analysis. Of these, 49 were solo works and 42 were joint publications. In total, 130 individual authors could be identified. Of the 130, three were unidentified, four were affiliated with researchbased NGOs, seven were affiliate $\mathrm{d}$ with differ ent levels of government (including one intergovernmental organization), and 115 we re $m$ embers of the academ ia (including professors, graduate students, research ass istants, intern ational lec turers, af filiated researchers, and post-doctoral fellows).

The academ ic community was represen ted by the following 26 disciplines : anthropology (5), business adm inistration (1), crim inology (1), cultural diversity and citizenship (1), culture, organization and $\mathrm{m}$ anagement (1), dem ography (1), econom ics (12), education (10), geography (9), health sc iences including psychiatry and psychology (9), his tory (1), inte rnational re lations (1), Is raeli and Middle Eas ters s tudies (1), linguistics (1), m anagement (1), m arketing (1), nursing (4), philosophy (2), political science (8), religious studies (1), social science (7), social work (6), sociology (26), urban planning (1), urbanization, culture and societ y (2), wom en's studies (1), and one was unidentified. The predom inant disciplines cont ributing to im migration research are thus sociology, economics, education, geography, health sciences, political science, and social science.

With respect to solo $\mathrm{p}$ ublications, two were governm ent sources, three were NGOs, one was unidentified, and 43 were academ ic. Of the 43 academ ic works, 
sociology was by far the predom inant academic contributor with 15 publications. Th at's just over half of all the sociology authors. Social sciences accounted for four (4) works ; economics, political science and health sciences accounted for three (3) each ; two (2) works each were con tributed by education, g eography and social anthropology ; and single works were produced by crim inology, cultural diversity and citizenship, demography, history, international relati ons nursing, religious studies, and urban planning. One academic discipline was unidentified.

With respect to joint publications, 15 disciplines were represented: anthropology (3), business administration (1), culture, organization and management (1), education (8), geography (7), health sciences (6), nursing (3 ), Israeli and Middle Eastern studies (1), linguistics (1), political science (5), social science (3), social work (6), sociology (11), urbanization, culture and society (1), and women's studies (1). Table 2 summarizes th e information regarding solo and joint publications.

Table 2 - JIMI, Solo and Joint Publications by Academic Discipline

\begin{tabular}{|l|c|c|c|}
\hline $\begin{array}{l}\text { Academic } \\
\text { discipline }\end{array}$ & Total \# of publications & Solo publications & $\begin{array}{l}\text { Joint } \\
\text { publications }\end{array}$ \\
\hline Anthropology 5 & & 2 & 3 \\
\hline $\begin{array}{l}\text { Business } \\
\text { administration }\end{array}$ & $1--$ & & 1 \\
\hline Criminology 1 & & & -- \\
\hline $\begin{array}{l}\text { Cultural divers ity } \\
\text { and citizenship }\end{array}$ & 11 & & 1 \\
\hline $\begin{array}{l}\text { Culture, } \\
\text { organization and } \\
\text { management }\end{array}$ & $1-$ & & - \\
\hline Demography 1 & & & - \\
\hline Economics 12 & & 3 & 9 \\
\hline Education 10 & & 2 & 7 \\
\hline Geography 9 & & 2 & 3 \\
\hline Health sciences & & 3 & -- \\
\hline Nursing 4 & & 1 & -- \\
\hline History 1 & & 1 & - \\
\hline International 1 & & 1 & \\
\hline
\end{tabular}




\begin{tabular}{|l|c|c|c|}
\hline relations & & & 1 \\
\hline $\begin{array}{l}\text { Israeli and Middle } \\
\text { Eastern studies }\end{array}$ & $1--$ & -- & 1 \\
\hline Linguistics 1 & & & \\
\hline Management 1 & & & \\
\hline Marketing 1 & 8 & 3 & -- \\
\hline Philosophy 2 & 1 & 1 & 3 \\
\hline Political science & 7 & 4 & 6 \\
\hline Religious studies & 6 & -- & 11 \\
\hline Social science & & 15 & -- \\
\hline Social work & 1 & 1 & 1 \\
\hline Sociology 26 & $2-$ & & 1 \\
\hline Urban planning & & -- & 42 \\
\hline $\begin{array}{l}\text { Urbanization, } \\
\text { culture and society }\end{array}$ & 1 & $\mathbf{4 9}$ & \\
\hline Women's studies & $\mathbf{9 1}$ & & \\
\hline Unidentified 1 & & & \\
\hline Total & & & \\
\hline
\end{tabular}

As Table 2 illus trates, of the 26 academ ic discip lines repres ented, the ones accounting for $\mathrm{m}$ ultiple publications were e ither pred ominantly joint publications (economics, education, geography, health scie nces, nursing, and social work) or had a relatively equal distribution of solo and jo int publications (politi cal science, social sciences, a nd socio logy). None of the multiple $p$ ublication contr ibutors were predominantly solo publications with the single possible exception of sociology, but even there the difference between solo and joint pub lications was fairly minor. The rest of the disciplines had only a single publication, which did not produce a large enough sample to determine the authorship dynamics in those cases.

Of the 42 partnerships, 21 were within th e sam e dis cipline/organizational platform, 16 were m ultidisciplinary, four were between different sectoral affiliation (e.g. academic and government), and one included authors whose affiliation was unidentified. Of the 21 partnerships with in th e sam e discipline /organizational pla tform, one was 
between governm ent sources, five were in eco nomics, four in soci ology, three each in geography and health sciences, two were in e ducation, and one each in political science, social scien ce, and culture, organ ization and $\mathrm{m}$ anagement. Of the four intersectoral publications, to were between governm ent wo rkers and sociologis ts, one between an NGO and geographers, and one between a government worker, a philosopher, a sociologist, and an anth ropologist. Finally, of the $16 \mathrm{~m}$ ultidisciplinary partnerships, two were between sociology and anthropology, tw o between education and econom ics, and one each of the following: linguistics and social work; Israeli and Middle Eastern stu dies and socio logy; social work a nd wom en's stud ies; so cial scie nce, po litical scien ce, and sociology; philosophy and political science; political science and business administration; urbanization, culture and society and soci al work; sociology, psyc hology and education; political science and sociology; sociology and marketing; social work and education; and social work, urbanization, culture and management, and sociology.

Among the 91 articles, 12 broad topics coul $\mathrm{d}$ be identified by grouping together articles with sim ilar research focus: ec onomic aspects of $m$ igration (including labour market outcom es, career $\mathrm{m}$ obility, wages, eco nomic benefits of $\mathrm{m}$ igration, acces $\mathrm{s}$ to regulated professions, credentials recognition, occupational injury, foreign workers, business m igrants, and brain dr ain), research an d policy (i ncluding policy debates and selectivity of $\mathrm{m}$ igrants), immigran $\mathrm{t}$ inte gration (including so cial integration, acculturation, assim ilation, settlement, and second generation $\mathrm{m}$ igrants), education (including academic perfor mance of imm igrant children and youth and the educational attainment of $m$ igrants), refugees ( $\mathrm{i}$ ncluding resettlem ent and sponsorship), multiculturalism, citiz enship and na tionalism (including tra nsnationalism and inclusion 
and exclusion), urban aspects of imm igration (including cities, housing, political participation, and political represen tation), religion, racism and discrimination (including social $\mathrm{m}$ obility), illegal $\mathrm{m}$ igration (includi ng un documented $\mathrm{m}$ igrants a nd traf ficking), and other (including regional $\mathrm{m}$ igration, hi story of $\mathrm{i}$ mmigration, and dem ographic profiles). A mong these them es, the topics gett ing the $m$ ost attention were in econom ic aspects of migration (26), immigrant integrati on (10), and urban aspects of migration (8).

The remaining categories contained between 3 and 6 sources each. Table 3 provides more detailed information on the distribution of articles by each broad topic category.

Table 3 - JIMI, Article Distribution by Topic

\begin{tabular}{|c|c|c|}
\hline Topic category & Specific focus by topic category & Total $^{4}$ \\
\hline $\begin{array}{l}\text { Economic aspects of } \\
\text { migration }\end{array}$ & $\begin{array}{l}\text { Language and employment }-1 \\
\text { Economic integration/labour m arket outcom es } \\
-5 \\
\text { Employment equity }-1 \\
\text { Employment }-4 \\
\text { Immigrant entrepreneurship }-1 \\
\text { Career mobility }-1 \\
\text { Access to regulated professions }-1 \\
\text { Credentials recognition }-1 \\
\text { Wages }-1 \\
\text { Tax-benefit analysis of immigration }-1 \\
\text { Socioeconomic wellbeing }-1 \\
\text { Human capital and employment }-1 \\
\text { Naturalization and employment }-1 \\
\text { Occupational injury }-1 \\
\text { Practicing traditional Chinese medicine }-1 \\
\text { Economics and citizenship - } 1 \\
\text { Business migrants }-1 \\
\text { Foreign workers }-1 \\
\text { Brain drain - } 1\end{array}$ & 26 \\
\hline Research and policy & $\begin{array}{l}\text { Research and policy }-2 \\
\text { Immigration policy }-1 \\
\text { Policy debates }-1 \\
\text { NGOs and the future of migration debate }-1 \\
\text { Immigrant selection and immigration }-1\end{array}$ & 6 \\
\hline
\end{tabular}

\footnotetext{
${ }^{4}$ The totals do not add to 91 because 4 works are not included on the account that their focus could not be determined. This includes two introductions to specific journal issues.
} 


\begin{tabular}{|c|c|c|}
\hline $\begin{array}{l}\text { Immigrant } \\
\text { integration }\end{array}$ & $\begin{array}{l}\text { Social integration }-1 \\
\text { Immigrant incorporation }-3 \\
\text { Assimilation }-1 \\
\text { Acculturation }-1 \\
\text { Poverty and integration }-1 \\
\text { Identity }-1 \\
\text { Second generation integration }-1 \\
\text { Settlement }-1\end{array}$ & 10 \\
\hline Education & $\begin{array}{l}\text { Children and youth (education) }-1 \\
\text { Academic performance of immigrants }-2 \\
\text { Immigrant concentration and education al } \\
\text { attainment }-1 \\
\text { Religion and educational attainment - } 1\end{array}$ & 5 \\
\hline Refugees & $\begin{array}{l}\text { Refugee resettlement }-2 \\
\text { Refugee integration }-1 \\
\text { Sponsorship and resettlement }-2\end{array}$ & 5 \\
\hline Multiculturalism & $\begin{array}{l}\text { Social capital and multiculturalism - } 1 \\
\text { Multiculturalism - } 3\end{array}$ & 4 \\
\hline $\begin{array}{l}\text { Citizenship and } \\
\text { nationalism }\end{array}$ & $\begin{array}{l}\text { Citizenship and nationalism }-1 \\
\text { Inclusion and exclusion }-2 \\
\text { Transnationalism }-1\end{array}$ & 4 \\
\hline $\begin{array}{l}\text { Urban aspects of } \\
\text { immigration }\end{array}$ & $\begin{array}{l}\text { Political participation }-2 \\
\text { Political incorporation }-1 \\
\text { Metropolitan migration }-4 \\
\text { Housing }-1\end{array}$ & 8 \\
\hline Religion & $\begin{array}{l}\text { Urban religion }-1 \\
\text { Religious diversity }-2\end{array}$ & 3 \\
\hline $\begin{array}{l}\text { Racism and } \\
\text { discrimination }\end{array}$ & $\begin{array}{l}\text { Ethnicity and social mobility }-1 \\
\text { Ethnicity, social capital and earnings }-1 \\
\text { Ethnicity and political representation }-1 \\
\text { Discrimination }-1 \\
\text { Racism - } 2\end{array}$ & 6 \\
\hline Illegal migration & $\begin{array}{l}\text { Illegal migration }-2 \\
\text { Undocumented migrants }-1 \\
\text { Trafficking }-1\end{array}$ & 4 \\
\hline Other & $\begin{array}{l}\text { Demographic profiles }-2 \\
\text { Regional migration }-1 \\
\text { Charitable giving among immigrants }-1 \\
\text { Slavic brides }-1 \\
\text { History or immigration }-1\end{array}$ & 6 \\
\hline
\end{tabular}

Further, a number of these works focuse d on specific groups of migrants (defined either geographically, by ethnicity, or according to various d emographic markers such as 
age, imm igration status, etc.) or on part icular geographic regi ons. The specific groups targeted in this s ample were ref ugees (including further $f$ ocus on wom en or specific regional origins), ethnic or re ligious groups (Chinese, Turks, Moroccans, Slavs, S outh Asians, Africans, Ghanains, Muslims), ch ildren and youth, business migrants, second generation $\mathrm{m}$ igrants, trafficked wom en, forei gn workers, and students. The particular geographic regions included ci ties (Toronto, Vancouver, M ontreal, B russels, Munich, Vienna), Canadian provinces (Alberta, Montreal, Quebec), countries (Canada, U.S., the Netherlands, Australia, Norway, Britain, France, Germany, Hong Kong, Sweden, Spain, Philippines, Switzerlan d, Lebanon, Finland) , and geographic and political regions (Europe, Subterranean Africa, European Union).

\section{BIBLIOGRAPHY ON IMMIGRATION AND SETTLEMENT IN THE TORONTO AREA}

The selection process f or Michael Doucet's Bibliography produced a list of 91 articles. Of these, 70 were solo works a nd 21 were joint publications. In total, 125 individual authors were iden tified. Of the 125 authors, $1 \quad 00$ were af filiated with the academic community, eight with various govern ment agencies, 13 with the NGO sector, one was an independent statutory body (Ont ario Human Rights Co mmission), and three could not be identified.

Of the eight governm ent-affiliated contributors, three were $f$ rom the Departm ent of Canadian Heritage, two f rom the Ontario Adm inistration of Settlement \& Integ ration Services (OASIS), and three from Statistics Canada. Of the 13 NGO contributors, fou $r$ were prim arily advocacy-based, four were fu nders, one w as research-based, and four 
were service-based. However, of the four pr imarily service-based contributors, two were also involved in research and advocacy.

Among the 100 academ ic contrib utors, 19 different acad emic disciplines an d programs of study were represented: aboriginal studies (1), anthropology (4), architecture (1), Canadian studies (1), communications (1), criminology (1), demography (1), tourism (1), economics (2), education including ea rly childhood education (23), geography (9), health sciences (18), infor mation studies (1 ), immigration and settlement studies (6), political science (2), social sc iences (2), social work (6), sociology (11), urban planning (4), and five (5) could not be identified. T he five academ ic contributors whose disciplinary affiliation could not be established were all graduate students whose schools and /or programs of study did not provide easy access to graduate theses.

With respect to the 70 so lo publications, seven (7) were contributed by NGOs , three (3) by the governm ent, one (1) by Ontario Hum an Rights Comm ission, one (1) could not $\mathrm{b}$ e identified, and the rem aining 58 were acad emic works. Am ong the 58 academic works, the fiv e most predominant disciplines were education (14), geography (7), immigration and settlem ent studies (6), health sciences (5) and sociology (5). The remaining academic disciplines can be seen in Table 4 below.

Table 4 - Doucet Bibliography, Solo and Joint Publications by Academic Discipline

\begin{tabular}{|l|c|c|c|}
\hline $\begin{array}{l}\text { Academic } \\
\text { discipline }\end{array}$ & $\begin{array}{l}\text { Total \# of } \\
\text { publications }\end{array}$ & Solo publications & Joint publications \\
\hline Aboriginal studies & 1 & 1 & --- \\
\hline Anthropology & 431 & & $-\cdots$ \\
\hline Architecture & 11 & & -- \\
\hline Canadian studies & 11 & & -- \\
\hline Communications & 11 & & \\
\hline
\end{tabular}




\begin{tabular}{|c|c|c|c|}
\hline Criminology 1 & & ---- & 1 \\
\hline Demography & 11 & & --- \\
\hline Economics & $2--$ & -- & 2 \\
\hline Education 23 & & 14 & 9 \\
\hline Geography & 972 & & \\
\hline Health sciences & 185 & 13 & \\
\hline Information Studies & 1 & 1 & --- \\
\hline $\begin{array}{l}\text { Immigration and } \\
\text { Settlement Studies }\end{array}$ & 66 & & --- \\
\hline Political Science & 2 & 2 & --- \\
\hline Social Science & 211 & & \\
\hline Social Work & 633 & & \\
\hline Sociology 11 & & 5 & 6 \\
\hline Tourism 1 & & 1 & --- \\
\hline Urban planning & 4 -- & ---4 & \\
\hline Unidentified 5 & & 5 & --- \\
\hline Total & 10058 & & 42 \\
\hline
\end{tabular}

When it cam e to joint publica tions (see Table 4), of the 21 collabor ations, the majority -14 - were within the sam e di scipline or organizati on: urban planning, education (2), sociology, econom ics, health sciences (2), geog raphy (3), social work (2), government, and NGO (2). Five collaborations were multidisciplinary in nature - health sciences and social work; health sciences and sociology; sociol ogy and anthropology; social sciences and crim inology; and soci ology, urban planning, a nd unidentified - and three collaborations were cross-sectora 1 : govern ment and urban planning, and NGO, sociology and urban planning. 
It can be noted from the above tabl e that among the acade mic contributors, anthropology, education, and geography were pr imarily in the form of solo publications; health sciences and urban planning in the for $\mathrm{m}$ of joint publications; and social work and sociology had an even distri bution of solo and join t $\mathrm{p}$ ublications. The re st of the academic disciplines $d$ id not produ ce a larg e enough sam ple to $d$ etermine the prim ary nature of authorship type. Immigration and settlem ent st udies is excluded from this observation because it is a program of study, not an academic discipline and every single contribution was by a graduate student.

Among the 91 articles, 12 broad research $\mathrm{t}$ opics could be iden tified, which were not all the sam e as in JIMI: labour $\mathrm{m}$ arket (including econom ic integration, ethnic entrepreneurship, and access to professions ), settlem ent and integration (including settlement services, settlem ent needs, soci al participation, acculturation, and eth nic identity), education (including ethnic schools, heritage education, and language learning), urban aspects of $\mathrm{m}$ igration (including hous ing, hom elessness, ethnic neighbourhoods, residential $\mathrm{m}$ obility, and cha nging urba $\mathrm{n}$ spaces), $\mathrm{m}$ ulticulturalism (including bilingualism, cultural exoticism , m edia por trayal, and ethn ic literatu re), racism , citizenship and nationalism (including transna tionalism, exclusion, re turn migration, and policy issues), religion, heal th (including $\mathrm{m}$ ental healt $\mathrm{h}$, health care, and $\mathrm{f}$ emale circumcision), dem ographic $\mathrm{p}$ rofiles ( including diaspo ras, ethn ic co mmunities, and comparative demographic profiles), family (including ethnic parenting, immigrant family dynamics, and international adoption), a nd other (including advocacy, community research, illegal $\mathrm{m}$ igrants, child refugee claim ants, queer Muslim $\mathrm{s}$, and Toronto immigration history). $\mathrm{T}$ he $\mathrm{m}$ ost researched to pics were settlem ent and integration (14 
articles), education (13), dem ographic profiles (10), and m ulticulturalism (9). W ith the exception of religion (2), the remaining categories were not too far behind, with seven (7) mentions each for urban and labou $\mathrm{r}$ m arket as pects, s ix (6) each for citizensh ip and health, five (5) for racism , and four (4) for fam ily. Table 5 provides $\mathrm{m}$ ore detailed information on article distribution by topic.

Table 5 - Doucet Bibliography, Article Distribution by Topic

\begin{tabular}{|c|c|c|}
\hline Topic category & Specific focus by topic category & Total \\
\hline Labour market & $\begin{array}{l}\text { Economic integration }-1 \\
\text { Access to regulated professions }-1 \\
\text { Ethnic entrepreneurship }-34 \\
\text { Employment }-1\end{array}$ & 7 \\
\hline $\begin{array}{l}\text { Settlement and } \\
\text { integration }\end{array}$ & $\begin{array}{l}\text { Information needs of service providers }-1 \\
\text { Immigrant settlement needs }-1 \\
\text { Settlement services }-4 \\
\text { Continental African service providers }-1 \\
\text { Identity }-4 \\
\text { Social participation }-1 \\
\text { Acculturation }-1 \\
\text { Diasporas }-1\end{array}$ & 14 \\
\hline Education Education & $\begin{array}{l}\text { Education and ethnic heritage }-2 \\
\text { Muslim educational institutions }-1 \\
\text { Holocaust education }-1 \\
\text { Language learning/teaching }-3 \\
\text { Teacher education }-1 \\
\text { Schools }-1 \\
\text { Youth engagement }-1 \\
\text { Youth careers }-1\end{array}$ & 13 \\
\hline $\begin{array}{l}\text { Urban aspects of } \\
\text { migration }\end{array}$ & $\begin{array}{l}\text { Homelessness }-3 \\
\text { Housing }-1 \\
\text { Changing urbanity }-1 \\
\text { Residential mobility }-1 \\
\text { Faith based ethnic neighbourhoods }-1\end{array}$ & 7 \\
\hline Multiculturalism & $\begin{array}{l}\text { Multiculturalism and media }-1 \\
\text { Multiculturalism }-4 \\
\text { Multiethnicity }-1 \\
\text { Cultural exoticism }-1 \\
\text { Ethnic literature }-1 \\
\text { Bilingualism }-1\end{array}$ & 9 \\
\hline Racism & $\begin{array}{l}\text { Racism }-4 \\
\text { Racial profiling }-1\end{array}$ & 5 \\
\hline
\end{tabular}




\begin{tabular}{|c|c|c|}
\hline $\begin{array}{l}\text { Citizenship and } \\
\text { nationalism }\end{array}$ & $\begin{array}{l}\text { Transnational communities }-3 \\
\text { Citizenship and exclusion }-1 \\
\text { Return migration }-1\end{array}$ & 6 \\
\hline Religion & Religion -2 & 2 \\
\hline Health & $\begin{array}{l}\text { Mental health }-2 \\
\text { Immigrant health }-1 \\
\text { Immigrant women abuse }-1 \\
\text { Female circumcision }-1 \\
\text { Health care }-1\end{array}$ & 6 \\
\hline $\begin{array}{l}\text { Demographic } \\
\text { profiles }\end{array}$ & $\begin{array}{l}\text { Francophone community }-1 \\
\text { Soviet Jews }-1 \\
\text { Chinese Canadians }-3 \\
\text { Black Canadians }-3 \\
\text { Little Portugal }-1 \\
\text { Comparative demographic patterns }-1\end{array}$ & 10 \\
\hline Family & $\begin{array}{l}\text { Cultural child rearing/ethnic parenting }-2 \\
\text { Family dynamics }-1 \\
\text { International adoption }-1\end{array}$ & 4 \\
\hline Other & $\begin{array}{l}\text { Queer Muslims }-1 \\
\text { Children seeking refugee status }-1 \\
\text { Toronto history of immigration }-1 \\
\text { Policy issues }-1 \\
\text { Community research }-1 \\
\text { Advocacy }-1 \\
\text { Illegal migrants }-1 \\
\text { City guide (travel) }-1\end{array}$ & 8 \\
\hline
\end{tabular}

An overwhelming 65 articles also focuse d on particular immigrant groups, with more than 26 different ethni c groups alone researched. The five ethnic groups with the most m entions were the Chinese, Portugue se, Japanese, South Asian, and the Black community in Toronto. The Chinese community in particular was very well re searched, with 12 articles focusing on different aspe cts of this community, ranging from Chinese immigrant women parenting practices to Chines e entrepreneurs to transnational practices in the Chinese comm unity. Am ong the m ost researched dem ographic groups were children and youth (15 articles), women (9), and entrepreneurs (4). 


\section{ANALYSIS}

As expected from a sch olarly peer-reviewed jou rnal, the ov erwhelming majority of publications were produced by author $\quad \mathrm{s}$ in the academ $\quad$ ia. $88.5 \%$ of individual contributors were m embers of the academ ia. Doucet's Bibliography was not far behind, with $80 \%$ o f the identif ied authors affiliated with the ac ademia. This was a little more surprising $\mathrm{b}$ ecause this partic ular publication referenced a m uch greater $\mathrm{v}$ ariety of research on imm igration. Am ong the works cited were books, $\mathrm{m}$ onographs, graduate theses, book chapters, journal articles, and res earch repor ts, inclu ding som e relatively obscure publications such as community/agency-developed reports. Despite this much greater sco pe, however, the vas $\mathrm{t} \mathrm{m}$ ajority of works in the exam ined sam ple were academic.

Of the 26 academ ic disciplines and pr ograms of study found in JIMI and the 19 found in Bibliography, 12 disciplines appeared in both publicati ons: anthropology, criminology, dem ography, economics, educati on, geography, health sciences, political science, social science, social work, soci ology, and urban planning. Incidentally, with a few exceptions, these w ere also the discip lines with the largest num ber of contributions. These are detailed in Table 6 below.

Table 6 - JIMI and Doucet, Top 12 Contributing Disciplines

\begin{tabular}{|l|c|c|}
\hline Discipline & JIMI & Doucet \\
\hline Anthropology 5 & & 4 \\
\hline Criminology 1 & & 1 \\
\hline Demography 1 & & 1 \\
\hline Economics 12 & & 2 \\
\hline Education 10 & & 23 \\
\hline Geography 9 & 9 & 9 \\
\hline Health sciences & 8 & 18 \\
\hline Political science & & 2 \\
\hline
\end{tabular}




\begin{tabular}{|l|c|c|}
\hline Social science & 7 & 2 \\
\hline Social work & 6 & 6 \\
\hline Sociology 26 & & 11 \\
\hline Urban planning & 1 & 4 \\
\hline
\end{tabular}

Doucet's Bibliography involved seven disciplines th at did not appear in JIMI: aboriginal studies, arch itecture, Canadian studies, communications, information studies, immigration and settlement studies, and touris m. JIMI, on the other hand, included twice as many disciplines that did not appear in Bibliography: business administration, cultural diversity and citizens hip, culture orga nization and $\mathrm{m}$ anagement, nursing, history, international relations, Israeli and Middle Eastern studies, linguistics, $\mathrm{m}$ anagement, marketing, philosophy, religious studies, urba nization culture and society, and women's studies. Some of these were due to contribu tions by inter national sch olars and s imilar disciplinary affiliations simply do not exist in Canada. Eight of the $14 \mathrm{~d}$ isciplines were due to contributions by international scholars. However, the remaining six were Canadian contributions and the fact that there are dis crepancies in dis ciplinary participation in the two publication venues suggests that certai $\quad \mathrm{n}$ aspects of imm igration research are particular to the natio nal while o thers to the local s cale. Further, five of the eight disciplines contributed by international sc holars - nam ely business adm inistration, history, international relations, linguistics, and philosophy - do exist in Canada as well, yet Canadia n scholars af filiated with these disciplines did not appear in the articles examined in this study. The num ber of contri butions by each discipline also seem s to suggest that som e immigration issues are ge tting more attention on the national than on the local scale, and vice versa. Table 7 shows the five biggest contributing disciplines in each publication in order of importance. 
Table 7 - JIMI and Dooucet, Top Five Contributing Disciplines in Rank Order

\begin{tabular}{|l|l|l|}
\hline Publication & JIMI & Doucet \\
\hline Discipline Sociology & \multicolumn{1}{|c|}{$(26)$} & Education (23) \\
\hline Discipline & Economics (12) & Health sciences (10) \\
\hline Discipline Education & Geography (9) & Sociology (11) \\
\hline Discipline & Health Sciences (9) & Geography (9) \\
\hline Discipline & Social work (6) \\
\hline
\end{tabular}

While the top five disciplines are almost identical - with four out of five being the same in the two publications, their importance in each case $\mathrm{v}$ aries sign ificantly when we consider the numbers themselves. Sociologists are twice as active on the national forum than they a re on the loc al, while th e reverse is true f or health scientists and educators. Interestingly enough, $g$ eographers hold th e same positio $\mathrm{n}$ in bo th forum $\mathrm{s}$, while economists are only active on the national scale. This is interesting when we consider that seven of the 91 Bibliography articles exam ined here res earch econo mic aspects of immigration, suggesting that on the local level topics such as immigrant employment and their econo mic integration lend the mselves to exploration by other disciplines. In this particular case, imm igrant and ethnic entrep reneurship was researched by two separate geographers and a collaborative team of gove rnment officials and an urban planner (3 articles in to tal); access to regulated prof essions by Imm igration and Settlem ent Studies graduate student; econom ic integration by an NGO; and immigrant employ ment by a sociologist. One possible explanation for this is the limitation of this study with respect to sample size. It is possible that the sample was not large enough to encompass the entire range of disciplines present in each public ation. A m ore detailed study could either reduce the discrepancies or confirm and even widen the apparent divergence. 
One notable disciplinary absentee on both the national and the local sca les is the faculty of history. Of the 215 ac ademic contributors identifi ed in the two sam ples, only one was af filiated with the depar tment of history. This is highly surp rising conside ring that immigration history is a very significant subject in the field of immigration. In the case of JIMI, one possible expl anation is th e nature of the journa 1 itse lf. JIM I is a relatively new - having been in existence fo $r$ only eight years - contem porary journal that, by virtue of being a Metropolis $\mathrm{P}$ roject public ation, has a very clear policy orientation. Since policy is by nature concerned with the present and the immediate future defined by short political term $\mathrm{s}$, this is not a forum conduc ive to the engagem ent of historians. In the case of Doucet, this could very well be a prim e example of the study limitations mentioned previously in the m ethodology section. Since only a s mall number of the Bibliography articles were sa mpled, it is possible that historians sim ply did not make this list. Further research will easily answer this question.

JIMI had a relatively ev en distribution of joint publ ications (53.8\%) and solo works (46.2\%), while the Bibliography sam ple was pred ominantly c omprised of solo publications, to the tune of $77 \%$. J IMI had 42 joint publications, while Bibliography contained 21. However, the total num ber of individual contributors from both the solo and the joint publications was almost id entical, with 130 for JIMI and 125 for Bibliography. Som e a cademic disciplines were $\mathrm{m}$ ore pr one to a particular type of authorship than others. In both cas es, publ ications produced by authors affiliated with health sc iences were predom inantly jo int collabor ations. In Bibliography, this predisposition towards joint publications was also demonstrated in urban planning, while anthropology, education, and geography produced predominantly solo publications. This 
was not the case with JIMI, where bot predominantly collaborative works, joined by econom ics, nursing, and social work. joint pub lications in JI MI, while this was not the case w ith any of the discip lines in Bibliography.

The type of collaborations also differed somewhat in each publications. Of the 42 joint pub lications identif ied in JI MI, the nu mber of those produced within th e sam e discipline/organizational platform was fairly close to th at of collaborations across different disciplines and sectors. Exactly half of the publica tions (21) were joint publications within the sam e discip line/organization, $16 \mathrm{w}$ ere $\mathrm{m}$ ultidisciplinary, a nd 4 were cro ss-sectoral. The Bibliography sam ple of joint works, on the other hand, was predominantly populated by collaborations with in the sam e discipline. Three quarters (14) of the 21 collaborative works identified in Bibliography were within the sam e discipline, five (5) were multidisciplinary, and three (3) cross-sectoral. In both JIMI and Bibliography, collaborations within the sam e academ ic discip line o r organiz ational platform we re alm ost identical. Both in cluded the government, econom ics, education, geography, health scien ces, and sociology. The Bibliography sam ple also inclu ded collaborations within the academic disciplines of urban planning and s ocial, as well as non-profit sector. The JIMI sample included political science, social science, and culture, organization and management.

The scope of $\mathrm{m}$ ultidisciplinary co llaborations was $\mathrm{m}$ uch greater in the JIM I sample, but both publications included anthro pology, health sciences, sociology, social work, and social s cience as common collabo rators. The Doucet sample also included 
criminology and urban planning in research partnerships, which the JIMI sample did not. The JIMI sample included education, econom ics, political science, and the $\mathrm{m}$ ore obscure contributors in linguistics , Israeli and Middle Easter n studies, philosophy, business administration, marketing, and urbanization, culture, and society.

With respect to research topics, certain differences can be observed between the two publications. The JIMI sam ple produced a greater scope of research, while the Bibliography sample produced research that was more focused. For example, while both publications included works on settlement and integration, Bibliography articles were the only ones to $\mathrm{m}$ ention settlem ent services and program s and the settlem ent needs of different groups of ne wcomers. Likewise, wh ile both publications treated a lot of the same research topics, these were approached differently by each. Econom ic aspects of immigration was a hot topic on the national ag enda (27 articles in JIMI), but did not garner nearly as $\mathrm{m}$ uch atten tion o $\mathrm{n}$ the $\mathrm{m}$ unicipal one (7 articles in Bibliography). Authors ad dressing ed ucation in JIMI focused on the academ ic perform ance of immigrant child ren an $\mathrm{d}$ the educa tional attain ment of adult $\mathrm{m}$ igrants, while authors writing abo ut education in Bibliography sources were $\mathrm{m}$ ore concerned with language learning among adult newcomers and ethnic schools for immigrant children. On the other hand, social inclusion, racism, and urban asp ects of i mmigration figured equally in both publications.

One of the $\mathrm{m}$ ain differences in res earch focus between the JIMI sam ple and the Bibliography sam ple is in the precision of re search focus. W hile both publications contain a large num ber of works that fo cus on a specific ethnic or dem ographic community of migrants (32 works in JIMI and 65 in Bibliography), articles found in JIMI 
do so on a much m ore varied geographic scale, while the Bibliography articles focus exclusively on Toronto (with th e exception of five sources th at also mention Vancouver, Montreal, Buffalo, Salk Lake City, Hong Kong, and Grenada). Of the 91 JIMI articles, 32 works address specific immigrant groups and 32 works fo cus on specific geographic regions. Th ese are actu ally th e sam e articles. W here a specific immigran t group was addressed, it was also speci fically stated in what geogr aphic region(s) this group was studied.

\section{DISCUSSION}

Immigration is a new field of study, and a rapidly expending one at that. The fact that scholarly journals and conferences de dicated specif ically to immigration exist suggests that imm igration is seen as an identifiable and unique field of study. Unlike established academ ic disciplines, however, it is a multidis ciplinary field whose dimensions are unclear. $\mathrm{W}$ hile there is now a handful of university program s dedicated specifically to the study of immigration ${ }^{5}$, professors teach ing courses in these program $\mathrm{s}$ and publishing books and articles on immigration come from a multitu de of disciplines,

\footnotetext{
5 Ryerson University's Immigration and Settlement Studies Program is the only postgraduate program in Canada dedicated t o t he st udy of i mmigration. I $\mathrm{n}$ a ddition, University of To ronto of fers a graduate collaborative p rogram in Ethnic and Pluralism Studies, wh ich allows Master's or Do ctoral stud ents working toward $\mathrm{s}$ an in terdisciplinary sp ecialization to com plete co urses ou tside of th eir department or faculty and receive a sp ecialized note on their transc ripts. Participating departments and faculties include: Anthropology, $\mathrm{C}$ entre $\mathrm{f}$ or European, R ussian, and Eurasian St udies (C ERES), G eography, Hi story, Industrial Relations and Human Resources (CIRHR), Nursing Science, Political Science, Religion, Social Work, Sociology, Sociology and Equity Studies in Education (SESE), Women and Gender Studies Institute (WGSI), as well as cert ain relevant co urse in the De partment of Ec onomics and t he Facul ty of Law. Similarly, Yor k U niversity's Centre f or Refu gee St udies of fers students enr olled in other p rograms to complete a specified list of c ourses to receive a General Certificate in Refugee \& Migration Studies, a Graduate Diploma in Refugee \& Migration Studies, or a Continuing Education Certificate in Refugee and Forced Migration Issues. Finally, Seneca College's Faculty of Continuing Education and Tra ining now of fers a Social Service Worker Immigrants and Refugees Diploma. It is pos sible that ot her programs exist of which I am not aware at this time.
} 
such as politics, geography, social work, urban planning, and early childhood education, to name a few. Just which academic disciplines make up this list can shed a light on what we consider the field of immigration to enco mpass. The way we institutionally carve up universities into school and departm ents and fi elds of study into disciplines reflects the way we draw bound aries aroun $\mathrm{d}$ academ ic e xpertise. "The actual sociopo litical organization of libraries, publishing houses, conf erences, and scholarly journals likew ise mirrors the sociom ental organization of the wo rld in general and of acad emic identity in particular.” (Zerubavel, 1995: 1093)

This study identified 33 different academ ic disciplines and area studies involved in immigration research. This represents a huge area of expertise and greatly diversif ies the kind of research being produced. This also makes it difficult to access the entire range of available research $b$ ecause each discip line has its own channels for dissem inating research findings, not all of which are easily accessible or even known to those outside of the dis cipline in ques tion. Further, of the 33 distinct disc iplines, program s and fie ld of study identified here, not all are involved in immigration research equally. In fact, only 11 disciplines and one graduate program (Im migration and Settlem ent Studies) have made any significant contributi ons in the sam ple examined in this study. This suggests that at the present, th e academ ia identifies immigration is sues predo minantly with the fields of anthropology, econom ics, educat ion, geography, health sciences, nursing, political sciences, social work, and sociol ogy. It should be furt her noted that while immigration as a field of study is new, i mmigration research is not and it would be interesting to see if the di sciplines involved in immigrati on research prior to 2000 were 
the same as identified here or if they ha ve changed over tim e. Further research beyond the scope of this study is required to answer this question.

With respect to multidisciplinarity, the examination of joint publications suggests that imm igration is a multidis ciplinary $\mathrm{f}$ ield and not an inte rdisciplinary one. A multidisciplinary field is one that draws on num erous disciplines in teaching a nd research, w hile an interdisciplinary field goes a step beyond by "integrating across existing disciplines to define appropriate objects of inquiry, methodologies, and modes of interpretation and analysis" (Katz, 2001: 524). While multidisciplinary collaborations do occur in im migration research, these seem to be $\mathrm{m}$ uch more pronounced on a national scale, while alm ost no nexistent on the loca 1 scale. JIMI, by virt ue of being a selfproclaimed multidisciplinary journal that emphasizes multidisciplinary, interdisciplinary, comparative, and policy-relevant research, at tracts publications th at cross the boundaries of traditionally compartmentalized discipline-specific knowledge. Doucet's Bibliography, on the other hand, sim ply com piles imm igration research on Toronto, which rem ains largely limited to exploration by individual disciplines. This is evidenced by the fact that of the joint collaborations that did occur, half of those in JIMI and nearly $80 \%$ of those in Doucet were within the same discipline. The relatively small volume of publications that reach across disciplinary boundaries suggests that immigration as a field of study has not yet reached the level of interdisciplinarity. This conclusion is based on the findings of this study and applies to imm igration research only. It is beyond the sc ope of this project to determ ine whether the academ ic instructio $n$ to stud ents enrolled in the handf $\mathrm{ul}$ of programs dedicated to the study of immigration that ex ist in Canada is perform ed at a multidisciplinary or an interdisciplinary level. 
The liter ature on au thorship its elf, albeit lim ited, invites som e interes ting questions about imm igration research. Se veral writers (Mountz, 2002; Valim aa, 1998; Zerubavel, 1995) have suggested that an author's identity affects re search in several important ways, from research $\mathrm{f}$ ocus to re lationship with $\mathrm{r}$ esearch subjec ts to the interpretation of findings. Our identities are constructed thr ough our dialogue with significant others (Taylor, 1994). In the case of academics, these sign ificant others can include disc iplinary co mmunities, prof essional association $\mathrm{s}$, institu tional comm unities, intellectual/epistemic traditions, national culture, and sociological categories such as race, gender, and class (Valimaa, 1998: 133). Considering these significant others in each case can allow us to ask practical research que stions more easily. Alison Mountz from the University of British Colum bia s eems to lend som e weight to this argum ent. She contends the ideas and methods she was in troduced to while studying feminist geography in the 1990s inform the way in w hich she de fines projects, asks questions, conducts research, and disseminates results. (2002: 188) According to her, our own id entities and the id entities of th ose with who m we work ed influ enced
every aspect of our project... Data were thus influenced by differential citizenship
histories, al ong with ot her p oints of di fference a nd ide ntification, s uch as race,
class, employment status, and gender (2002: 189). Mountz (2002) argues that in order to si tuate knowledge and establish a view from somewhere, data should always be presented in relation to the c ontext in which it was collected. The multidisciplinary nature of immigration as a field of study greatly expands the pool of these significant others, making it more difficult to contextualize the produced knowledge.

In view of the multidisciplinarity of the field of immigration, the question is how such a wide range of author iden tities affects immigration research. While I cannot even 
begin to an swer this q uestion without ex amining each individual work in detail something that is well beyond the scope of this research project - I can offer two observations derived fr om my study. First of all, ther $\mathrm{e}$ is an obvious link between the disciplinary af filiation of the auth or and the research top ic. For exa mple, a $r$ esearch interest receiving a lot o f attention in the Bibliography is children and youth. This is in direct co rrelation with the overwhelm ing presence of re searchers affiliated with the discipline of education. In a similar vein, the greater emphasis on the economic aspects of immigration in J IMI is in par $t$ due to a $g$ reater presen ce of scholars affiliated with the department of econom ics. This su ggests that academ ic areas of e xpertise are in deed compartmentalized and discip linary boundaries do exist. However, the fact that som e researchers - socio logists in particular, in exploring such wide topics as econom ic assimilation and educational attainments of immigrant groups- have crossed these boundaries suggests that disciplinary affiliation is not the only factor in the determination of research interests. $\mathrm{S}$ ince the natural cho ice of researc $\mathrm{h}$ topics wo uld norm ally lie within one's academ ic discipline, this suggests that other factors pertain ing to researcher's identity are involv ed. Furt her, while a researcher's academ ic or organizational af filiation $\mathrm{m}$ ay explain th e focus on a pa rticular topic, it is unab le to explain the researcher's focus on a particul ar ethnic com munity or a geographic area where this is the case.

Funding is also changing the nature of immigration research across the board. The Social Sciences and Hum an Research C ouncil (SSHRC) has shifted its focus fr om supporting traditional academic curiosity-driven research to funding projects that address specified policy concerns (Shields, 2007: 4) This approach, while potentially useful, 
needs to be treated with caution because it ha $\mathrm{s}$ the potential of dras tically changing the immigration research landscape. Policy $m$ aking is by nature a political process. The involvement of a multitude of politician s, bur eaucrats, lob byists, in terest groups and researchers brings a significant hum an elem ent to the process, $\mathrm{m}$ aking it unpredictable and volatile. As such, it $\mathrm{m}$ atters not only who produced the resear ch findings, but also who is goin $g$ to inte rpret them and what goals they are $m$ eant to supp ort. This ha s the potential to inadvertently com promise the in tegrity of immigration research by making it open to $\mathrm{m}$ anipulation. Shields points out that $\mathrm{k}$ nowledge absorption within governm ent can be hap hazard and inconsistent (Shiel ds, 2007: 9 ). As such, if the focus of immigration research is shifte $d$ to support political aim $s$, we risk losing sight of the big immigration picture. If resear ch interests are guided by po litical popularity of any given immigration issue, there is a gr eat potential for widening holes in immigration research. In addition, since any research that is largely dependent on governm ent funding is vulnerable to changing currents in public adm inistration, we must be wary of the future of immigration research should a new adm inistration or approach in governance change the perceived value of policy-oriented immigration research, research partnerships, or the Metropolis Project itself.

This has serious implications for the future development of immigration as a field of study and the way im migration research is absorbed. The desired policy orientation of immigration research may once again redefine the boundaries of immigration as a field of study, which we are just now in the process of establishing in the first place. $\mathrm{P}$ olicy making is by nature a short-si ghted process oriented toward the imm ediate future and little concerned with the past. The active direction of imm igration rese arch in this vein 
has the potential to create and widen gaps in knowledge generated by this field. One such gap - nam ely the absence of historians - is already ev idenced in the Me tropolis publication JIMI. If the trend towa rds the sh aping of imm igration research to address policy issues continues, the field risks compromising its truly multidisciplinary nature.

This trend is even more alarming when we consider the kind of research currently being produced. The examined sample shows that more than $80 \%$ of all research is being produced by the academia. This type of authorship results is traditionally associated with trusted obje ctivity and accura cy of inform ation but re lies on standard academic written dissemination outlets such as books and peer-reviewed acad emic journals, which have long publishing timelines, restricted access, and very limited audiences. As a result, any societal impacts of such resear ch take a considerable tim e to materialize (Shields, 2007: 3). If such research is actively directed to inform policy, it is not likely to do so in the required time frame. As a resu lt, we risk en ding up with research th at, while designed to address a particular policy area, fails to affect change should political priorities - or the administration itself - change before the resear ch project is complete. At the sam e time, the invo lvement in this proje ct $\mathrm{w}$ ill $\mathrm{h}$ ave pr evented th e resea rcher $\mathrm{f}$ rom pursuing a different topic.

Government initiated research also ta kes a lo ng tim e to com plete because it usually tak es a $f$ orm of reports com piled after leng thy nationa 1 consulta tions with stakeholders. (sentence removed) Knowledge produced by the service sector, on the other hand, is perhaps the most perceptive and practical because service providers are uniquely positioned at the in tersection of po licy, programming, and target communities (Sh ields, 2007: 10). Unfortunately, such knowledge fall s under the category of grey literature, 
confining it to the outskirts of knowledge production. Although th e Metropolis Project has done a great deal to put grey literatu re on the $\mathrm{m}$ ap, it continues to be inferior to academic research, $\mathrm{m}$ aking such findings eas $\mathrm{y}$ to dis count, particu larly when they contradict political aims. While Citizenship and Imm igration Canada (CIC) and SSHRC value the involvem ent of service providers in research 'partnerships,' it is the a cademics who occupy the privileged position of carrying the weight of the project. NGOs are there to help acad emics do better research through improved access to research subjects, but they are seen as too value charg ed a nd unqualified to $m$ eet research quality and objectivity standards to produce independent research to affect government policymaking (Shields, 2007: 12). As evidenced by the present study, immigration research remains the domain of academ ic scholarsh ip and only a small portio $\mathrm{n}$ of identif ied research was produced by the non-profit sector. The im plications of this are troubling when we consider policy im plications. If policy $\mathrm{m}$ aking is based on research and the research coming out of the onl y sector working direc tly with immigran ts is margina lized, the policy makers are then presented with a skewed picture. Further research is required to determine why the non-profit sector is not we 11 represented in imm igration research and what can be done to address this issue.

Overall, while this study is unable to definitively establis $\mathrm{h}$ the boundaries of immigration as a field of study - in light of the previously di scussed m ethodological limitations - it nevertheless provides a dire ction for further research. Expanding the sample of exam ined article $\mathrm{s}$ both in term $\mathrm{s}$ of num bers and the tim e period exa mined would help determ ine with a greater accuracy what the dim ension of this field are and whether or not these have shifted over ti me. In light of the changing nature of 
immigration research, it would also be desi rable to exam ine whether o $r$ not chang es in policy are reflected in immigration research an $d$ what is the nature of the link - if one exists - be tween the two. Finally, f urther discussions on in tegrating multiple disciplines would help provide direction on how to guide the future development of immigration as a field from multidisciplinarity to interdisciplinarity. 


\section{WORKS CONSULTED}

2000. Abu-Laban, Baha and Hans Vermeulen. "Introduction." Journal of International Migration and Integration, 1 (1), 1-3.

2008. Archer, Louise. "The New Neoliber al Subjects? Young/er academ ics' constructions of professional identity," Journal of Education Policy 23 (3), 265-285.

2008. Doucet, Michael and Hii, Rebecca. Bibliography on Immigration and Settlement in the Toronto Area, Third Edition. CERIS Working Paper No. 65. Available on http://ceris.metropolis.net

2000. Journal of International Migration and Integration 1 (1), Winter 2000.

2000. Journal of International Migration and Integration 1 (2), Spring 2000.

2000. Journal of International Migration and Integration 1 (3), Summer 2000.

2000. Journal of International Migration and Integration 1 (4), Fall 2000.

2001. Journal of International Migration and Integration 2 (1), Winter 2001.

2001. Journal of International Migration and Integration 2 (2), Spring 2001.

2001. Journal of International Migration and Integration 2 (3), Summer 2001.

2001. Journal of International Migration and Integration 2 (4), Fall 2001.

2002. Journal of International Migration and Integration 3 (1), Winter 2002.

2002. Journal of International Migration and Integration 3 (2), Spring 2002.

2002. Journal of International Migration and Integration: Special Double Issue 3 (3-4), Summer/Fall 2002.

2003. Journal of International Migration and Integration 4 (1), Winter 2003.

2003. Journal of International Migration and Integration. Special Issue: Private Sponsorship and Partnerships in Refugee Resettlement 4 (2), Spring 2003.

2003. Journal of International Migration and Integration 4 (3), Summer 2003.

2003. Journal of International Migration and Integration 4 (4), Fall 2003.

2004. Journal of International Migration and Integration 5 (1), Winter 2004. 
2004. Journal of International Migration and Integration 5 (2), Spring 2004.

2004. Journal of International Migration and Integration 5 (3), Summer 2004.

2004. Journal of International Migration and Integration 5 (4), Fall 2004.

2005. Journal of International Migration and Integration 6 (1), Winter 2005.

2005. Journal of International Migration and Integration. Special Issue: The ReEmergence of Religion in International Public Discourse 6 (2), Spring 2005.

2005. Journal of International Migration and Integration 6 (3-4), Summer/Fall 2005.

2006. Journal of International Migration and Integration 7 (1), Winter 2006.

2006. Journal of International Migration and Integration 7 (2), Spring 2006.

2006. Journal of International Migration and Integration 7 (3), Summer 2006.

2006. Journal of International Migration and Integration. Special Issue: Transnationalism and Migration: Chinese People on the Move 7 (4), Fall 2006.

2007. Journal of International Migration and Integration 8 (1), Winter 2007.

2007. Journal of International Migration and Integration. Special Issue: Accessing the Higher Echelons of a Host Country's Labour Market: Policy Directions from the Personal Experiences of Skilled Migrants 8 (2), Spring 2007.

2007. Journal of International Migration and Integration 8 (3), Summer 2007.

2007. Journal of International Migration and Integration. Special Issue: Issues of Workplace Discrimination and Employment Barriers 8 (4), Fall 2007.

2001. Katz, Cindi. “Disciplining Interdisciplinary,” Feminist Studies 27 (2), 519-525.

2002. Mountz, Alison. "Fem inist Politics, I mmigration, and Academ ic Identities," Gender, Peace and Culture 9 (2), 187 - 294.

2007. Shields, John. "Mobilizing Immigration Research for Policy Effect: The Case of CERIS.” CERIS Working Paper no. 58. Available on http://ceris.metropolis.net

1994. Taylor, Charles. "The Politics of Recognition" in Any Gutmann, ed. Multiculturalism: Examining the Politics of Recognition. Princeton, N.J.: Princeton University Press. 
1998. Valimaa, Jussi. "Culture and Identity in Higher Education Research," Higher Education 36 (2): 119-138.

1995. Zerubavel, Evitar. "The Rigid, the Fuzzy, and the Flexible: Notes on the Mental Sculpting of Academic Identity," Social Research 62 (4), 1093 - 1106. 


\section{APPENDIX A: JIMI Sample}

\section{Article}

"When is my Dutch good enough?"

Dutch labour organizations

A Canadian exceptionalism? Trust and diversity in Canadian cities

A framework for understanding crossnational differences in the relationship between research and policy

A note on Jeffrey Reitz' policy paper

A political economy approach to understanding the economic incorporation of Chinese sub-ethnic groups

Access and equity issues in employment and service provision for NESB

immigrants in New Zealand public sector organizations 2

Apport démographique de l'immigration internationale dans la région

Métropolitaine de recensement (RMR) de

Montréal, 1976-1996

Attitudes toward work: Ethnic minorities and immigrant groups in Vancouver

Beyond "Entry-level" Jobs: Immigrant

Women and Non-regulated Professional Occupations 2

Canadian immigration, mexican emigration, and a North American regional interpretation
Experiences of refugee women with

pub. Author

Year type

2006 multiple

2006 single

2001 single

2001 multiple

Baha Abu-Laban and Hans Vermeulen

Lucia Lo and $\mathrm{Lu}$

2004 multiple Wang 2

Noel Watts and Andrew Trlin

linguistics and social work

2005 single

Harald Bauder

geography

007 multiple

Liza McCoy and

Cristi Masuch

2 sociology

Capital social et vie associative de quartier en contexte multiethnique: Quelques réflexion à partir de recherches Montréalaises 2
004 single Annick Germain urban planning 
Career Nomadism and the Building of a

Professional Identity in Female

Immigrants 2

007 single Hélène Cardu education

Changing patterns of political participation of citizens of immigrant origin in the Brussels capital region: The October 2000 elections

2002 multiple

Charitable giving among the foreign-born in Canada

2000

Chinese immigrants in vancouver: Quo vadis? 2

Citoyenneté, nationalité et laïcité: Le

débat sur la France multiculturelle depuis les années 80

Closing the wage gap: Economic assimilation of Canadian immigrants reconsidered 2

Contesting sacred urban space:The case of the Eruv

006 multiple

Dirk Jacobs, Marco Martiniello and

Andrea Rea

Fernando Mata and

Don McRae

Shibao Guo and Don

J. DeVoretz

single

Yvan Gastaut

history

Derek Hum and

multiple

Wayne Simpson

single

Myer Siemiatycki

2 economics

political science

Diagnosing and preventing "brain waste"

in Canada's immigrant population: A

synthesis of comments on reitz

2001 single

Richard A. Wanner

sociology

Economic impacts of immigrants in the

Toronto CMA: A tax-benefit analysis

Ethnicity and social mobility: The case of

Turks in Germany

Ethnoracial Origins, Social Capital, and

Earnings

2000

multiple

Shuguang Wang and

2007 single

Lucia Lo

2 geography

Ethnoracial political representation in Toronto: Patterns and problems

2002 multiple

Myer Siemiatycki and Anver Saloojee

2 political science

Explaining the socioeconomic well-being of immigrants and returned migrants: An econometric analysis of the Hong Kong and Canadian censuses of 2001

Tian Fangmeng and Ma Zhongdong

2 social science

Facilitating the arrival of illegal

immigrants in the Netherlands: Irregular

chain migration versus smuggling chains

2004

Richard Staring

criminology 
Focusing on children and youth: The role of social capital in educational outcomes in the context of immigration and diversity 2

Genre et performance scolaire en milieu minoritaire au Quebec. Les élèves originaires d'Afrique subsaharienne

Getting a foothold: Male immigrant employment integration and structural change in Sweden, 1970-1995

Immigrant concentration and educational attainment: Evidence from US data Immigrant Employment Success in Canada, Part II: Understanding the Decline multiple

Yvonne Hébert, Xiaohong Shirley Sun

004 multiple and Eugene Kowch 3 education

Jean-Paul Mbuya

Mutombo and

Ghislaine Ngoie Wa

Bienge 2

gov
Immigrant intelligentsia and its second generation: Cultural segregation as a road to social integration?

Immigrant skill utilization in the Canadian labour market: Implications of human capital research single

Immigration and the metropolis: Reflections on urban history single

Include or exclude: Discourses on immigration in Germany

2002 single

Incorporating Muslim migrants in western nation states - a comparison of the United Kingdom, France, and Germany 2005

Institutional change and emerging cohorts of the "New" immigrant second generation: Implications for the integration of racial minorities in Canada

2004 multiple

Jeffrey G. Reitz and Kara Somerville 2 sociology

Introduction 2

000 multiple

Baha Abu-Laban and sociology and

Introduction 2

004 multiple
Hans Vermeulen

Jean Lock Kunz and

Peter S. Li Jeffrey G. Reitz sociology Alejandro Portes

sociology

Alexei Izyumov, Nan-

Ting Chou, Paul

Coomes and Babu

Nahata 4

economics

Isreali and Middle

Alek Epstein and NinaEastern studies and Kheimets Sociology

Dietrich Thränhardt political science anthropology

gov. and sociology 
Labour market integration of refugees in Norway under changing macro-economic conditions 2

Labour market outcomes of immigrant and racial minority university graduates in Canada 2

Laicity and religious diversity Quebec's approach: Report to the minister of citizen relations and immigration

003 multiple

Paul Anisef, Robert Sweet and George Frempong

Conseil des relations interculturelles $\mathrm{g}$ ov

Le logement des réfugiés à Montréal trois ans après leur arrivée: le cas des demandeurs d'asile ayant obtenu la résidence permanente

2001 multiple

Damaris Rose and Brian Ray

geography and ngo

Les dynamiques de la migration

contrainte: suivons le troupeau!

Les enjeux de l'entreprenariat immigré

Licensure of Internationally Educated Nurses Seeking Professional Careers in the Province of Alberta in Canada

Measuring up: Academic performance of Canadian immigrant children in reading, mathematics, and science
2005

single

Julie Kaizen

Antoine Pécoud

Linda Ogilvie, Barbara Leung, Terry Gushuliak, Marion McGuire and Elizabeth Burgess2007 multiple Pinto

Xin $\mathrm{Ma}$

education unidentified

sociology, psychology, education

unidentified academic social anthropology
Metropolitan migration in the past:

Labour markets, commerce, and cultural interaction in Europe, 1600-1914

Multicultural society under attack: Introduction 2

Multiculturalism and white paranoia in Australia

Naturalization and employment integration of Turkish and Moroccan immigrants in the Netherlands NGOs and the future of the migration debate 2

Occupational injury among immigrants single

2000 single

002 multiple

Baukje Prins and Boris Slijper

Ghassan Hage

Pieter Bevelander and

2006
multiple Justus Veenman 2 economics

000 single

Frank Sharry ngo Wilfreda Thurston 2003 multiple and Marja Verhoef social sciences philosophy, political science

social anthropology 
On immigrant integration: Reply to Stoffman

2004 single

Perceiving Discrimination: Psychological and Sociopolitical Barriers single

Kim C. Matthews

sociology

Practising traditional Chinese medicine in a Canadian context: The roles of immigration, legislation, and integration

2006

single

Lyren Chiu

nursing

Annick Lenoir-

Preface 2

007

multiple

Achdjian and Maryse social work and

Public-private partnerships in refugee

resettlement: Europe and the US

2003 single

Joanne van Selm ngo

Relationships between demographic variables and immigrant parents' perceptions of assimilative adolescent behaviours 2

002 multiple

Noorfarah Merali and

Claudio Violato 2 psychology

Religious identity and educational attainment among recent immigrants to Canada: Gender, age, and 2nd generation 2005 single

Peter Beyer religious studies

Residential concentration and participation in local politics: The case of immigrants of the FSU in Israel 2002 single

Selectivity and immigration in Canada

2002 multiple

\section{Gustavo S. Mesch \\ Derek Hum and}

sociology

Size Matters: Attracting New Immigrants

to Canadian Cities

Slavic brides in rural Alberta

2005 single

Social capital and refugee resettlement:

The social networks of refugees in Canada2003 multiple

Sponsorship and resettlement success

2003 single

Morton Beiser

psychiatry

Sponsorship: Organizational, sponsor, and refugee perspectives 2003 single Michael Lanphier sociology

State migrant-exporting schemes and their implications for the rise of Illicit migration: A comparison of Spain and the philippines 2

Christina Siracusa and political science and Kristel Acacio sociology 
Survival on the margins: Summary of a research project on undocumented migrants in Munich

social sciences

Sustaining a Strong Cultural and National Identity: The Acculturation of Immigrants and Second-generation Canadians of Asian and African Descent

The changing face of Chinese immigrants in Canada

single

Peter R. Grant psychology

2006 multiple Shibao Guo and Don education and J. DeVoretz economics

The Credentialing Problems of Foreign Trained Personnel from Asia and Africa Intending to Make their Home in Canada: A Social Psychological Perspective 2007 multiple

Peter R. Grant and Shevaun Nadin 2 psychology

The economic causes and consequences of Canadian citizenship 2005 multiple

Don J. DeVoretz and

The emergence of a South Asian business elite in the United Kingdom 2001 single Anuradha Basu economics

The Finnish red cross in refugee settlement: Developing the integration timeline as a tool for integration in the kotopolku project single Johanna Matikainen unidentified

The invisible barrier: Neighbourhood poverty and integration of immigrants in Canada 2

000 multiple

Abdolmohammad Kazemipur and Shiva Halli 2 sociology

Hakan Gürses, Barbara HerzogPunzenberger, Karl

The necessary impossibility: Dynamics of identity among young people of different backgrounds in Vienna 2001 Reiser, Sabine philosophy, Strasser and Dilek sociology, 2

The Past and Future of Immigration to Canada 2

007 single

David Verbeeten anthropology, gov.

The political incorporation of South Asian elites in Britain 2001 single

The politics of refugees' non integration: the dilemma of Palestinians in Lebanon multiple

Shamit Saggar social sciences

The Problem of Second-generation Decline: Perspectives on Integration in Canada 2

Shiva S. Halli and Vedanand sociology and marketing 
The Professional Insertion of Immigrants

Born in the Maghreb: Challenges and

Impediments for Intervention

The racial subtext in Canada's

immigration discourse
2007

2001
Annick LenoirAchdjian, Isabelle Drainville, Denise Helly, Sébastien Arcand, Michèle Vatz and society, 1 Laaroussi and Amel management, and 1 Mahfoudh sociology

Petr S. Li sociology

The starting line and the promotion of EU anti-discrimination legislation: The role of policy oriented research 2000

Toward a new modus vivendi between academic research and practical social policy 2

001 single

Wsevolod W. Isajiw sociology Jacqueline OxmanMartinez, Andrea

Trafficking women: Gendered impacts of Canadian immigration policies 2001 multiple Martinez and Jill

Transnationalism among African immigrants in North America: The case of Ghanaians in Canada

Travailleurs Étrangers sur le Marché du Travail Suisse: Quels Modes

D'incorporation? 2

007 single

Claudio Bolzman

2 social work, Hanley women's studies

Twinning projects between immigrant families and quebecois families:

Volunteer work, mutual aid, or intervention? 2

003 multiple

Johanne Charbonneau urbanization, culture and Michèle Vatz and society; and Laaroussi social work

Valorisation du multilinguisme et de l'éducation bilingue dans des familles immigrantes 2
$000 \quad$ Diane Dagenais and
Marianne Jacquet
2 education

What happened to the Canada-United States brain drain of the 1990s? New evidence from the 2000 US census

2006 single Richard E. Mueller economics 


\section{APPENDIX B: Bibliography sample}

\section{Publication}

ABDEL-SHEHID, Gamal. 2000. "Who Da' Man: Black Masculinities and Sport in Canada," PhD thesis, York University.

ABENS, Aija. 2003. "Changing Profile of Parents and Students in a Latvian Heritage Language School: A Twenty-Five Year Follow Up," MEd thesis, York University.

ABU-HATOUM, Nayrouz. 2007. "On the Borderzone: Toronto's Diasporic Queer Muslims," MA thesis, York University.

ACCESS ALLIANCE MULTICULTURAL COMMUNITY HEALTH CENTRE. 2003. Best Practices for Working with Homeless Immigrants and Refugees: A Community-Based Action-Research Project. Phase I: Research. Toronto: Access Alliance Multicultural Community Health Centre.

\section{Year $\begin{aligned} & \text { Author } \\ & \text { Type }\end{aligned}$}

$2000 \sin$ gle health sciences $2003 \sin$ gle education 2007 sin gle anthropology 2003 sin gle NGO

ADVOCATES FOR COMMUNITY-BASED TRAINING AND

EDUCATION FOR WOMEN. 2001. Challenges and

Connections: Meeting the Information Needs of Professionals Working with Immigrant Women. Toronto: and Connections: Meeting the Information Needs of Professionals Working with Immigrant Women. Toronto: Maytree Foundation.

AGARD, Rawle G. 2005. "Strange Fruit: The Reification of Race and the Myth of Official Multiculturalism in Selected Canadian Media," [analysis of the Toronto Star], MA thesis, $2005 \mathrm{sin}$ gle communications University of Windsor.

AGRAWAL, Sandeep Kumar and QADEER, Mohammad A. 2008. Faith-based Ethnic Residential Communities and Neighbourliness. CERIS Working Paper Series No. 63. Toronto: 2008 multiple 2 urban planning Joint Centre of Excellence for Research on Immigration and Settlement - Toronto. [Available at www.ceris.metropolis.net]

AHMAD, Farah; SHIK, Angela; VANZA, Reena; CHEUNG, Angela M.; GEORGE, Usha; and STEWART, Donna E. 2004. "Voices of South Asian Women: Immigration $2004 \mathrm{~m}$ ultiple 5 health sciences, 1 and Mental Health," Women and Health 40 (4), 113-130.

ALBOIM, N. 2002. Fulfilling the Promise: Integrating Immigrant Skills into the Canadian Economy. Toronto: Caledon 2002 sin gle NGO Institute of Social Policy.

ALI, Mehrunnisa; TARABAN, Svitlana; and GILL, Jagjeet Kaur. 2004. Unaccompanied/Separated Children Seeking Refugee Status in Ontario: A Review of Documented Policies and Practices. CERIS Policy Matters Series No. 13. Toronto: $2004 \mathrm{~m}$ ultiple 3 education Joint Centre of Excellence for Research on Immigration and Settlement. [Available at www.ceris.metropolis.net] 
ANISEF, Paul and LANPHIER, Michael (eds.) 2003. World in a $2003 \mathrm{~m}$ ultiple 2 sociology
City. Toronto: University of Toronto Press.

AZMI, Shaheen H.2001. "Muslim Educational Institutions in

Toronto, Canada," Journal of Muslim Minority Affairs $21 \quad 2001$ sin gle political science

(2), 259-272.

BEJAR, James. 2006. “Transnational Communities: Filipina

Nurses in Rural Manitoba 1965-1970," MRP, Immigration and 2006 sin gle ISS

Settlement Studies Program, Ryerson University.

BEYENE, W. Y. 2000. Settlement Service Needs for Ethiopian

Newcomers in Toronto. Toronto: Ethiopian Association in 2000 sin gle NGO

Toronto.

BOURHIS, Richard Y. 2003. "Measuring Ethnocultural

Diversity Using the Canadian Census," Canadian Ethnic Studies 2003 sin gle health sciences 35 (1), 9-32.

CAPPE, Brenda. 2007. "The Campaign for Holocaust Education

in Toronto: An Oral History," MA thesis, University of Toronto.

$2007 \mathrm{sin}$ gle education

CHAMBON, Adrienne S.; HELLER, Monica; KANOUTÉ,

Fasal; LABRIE, Normand; MADIBBO, Amal;

MAURY, John; and MALUBUNGI, Mueni. 2001.

L'immigration et la communauté franco-torontoise: Rapport

Centre de Recherches

final. Toronto: Centre de Recherches en Education Franco-

$2001 \mathrm{~m}$ ultiple

en Educaiton Franco-

Ontarienne. [Available at www.ceris.metropolis.net]

Ontarienne)

CHEONG, Yuan Mai. 2006. "Exoticism and East Asian

Women: Moving Beyond Geishas and Dragon Ladies," MRP,

Immigration and Settlement Studies Program, Ryerson

$2006 \sin$ gle

ISS

University.

CHOW, Wing-Hang A. 2003. "Pastoral Perceptions of Church

Ministry Functions in Canadian Chinese

Churches," [examines pastors in the Toronto Chinese

Evangelical Ministerial Fellowship], EdD thesis, Souther

$2003 \mathrm{sin}$ gle education

Baptist Theological Seminary.

CONTINENTAL AFRICAN SERVICE PROVIDERS. 2001.

Continental African Service Providers Conference. Continental

African Service Providers Conference. Toronto: Continental

$2001 \mathrm{sin}$ gle

NGO

African Service Providers.

DALI, Keren. 2004. "Reading by Russian-Speaking Immigrants

in Toronto: Use of Public Libraries, Bookstores,

and Home Book Collections," International Information and

2004 sin gle information studies

Library Review 36 (4), 341-366.

DAVIDSON, Thelma. 2001. "Former Soviet Jews in Toronto:

Post-Collapse of the Soviet Union," MA thesis, Trent

University.

2001 sin gle canadian studies

DE SILVA, Samangi N. 2003. "The Contested Terrain of

Citizenship and Exclusion in Canada: Sri Lankan Women's

Narrative Accounts of School and Social Experience in the

$2003 \mathrm{sin}$ gle unidentified

Diaspora," MA thesis, University of Toronto. 
DEROUIN, Jodey Michael. 2004. “Asians and Multiculturalism

in Canada's Three Major Cities: Some Evidence from the Ethnic 2004 sin gle gov

Diversity Survey," Our Diverse Cities 1 (Spring), 58-62.

DUNN, Samuel. 2004. "Building a Research Culture:

Perspectives from a Community Health Centre in Toronto," Our 2004 sin gle NGO

Diverse Cities 1 (Spring), 109-110.

DUVAL, David T.2004. "Linking Return Visits and Return

Migration among Commonwealth Eastern Caribbean

Migrants in Toronto," Global Networks 4 (1), 51-67.

$2004 \mathrm{sin}$ gle tourism

FIX, Elizabeth and SIVAK, Nadine. 2007. "The Growing Case for Youth Engagement Through Culture," Our Diverse Cities 4 (Fall), 145-151.

FLANDERS, John; CHUI, Tina; and TRAN, Kelly. 2005.

"Chinese Canadians: Enriching the Cultural Mosaic," Canadian 2005 multiple 2 gov, 1 urban planning

Social Trends, 76, 2-7.

FONG Eric; CHIU, Luk; and OOKA, Emi. 2005. "Spatial Distribution of Suburban Ethnic Business," Social Science Research 34 (1), 215-235.

FUNG, Kenneth P. 2003. "Study of Alexithymia in Chinese Canadians," M Sc thesis, University of Toronto.

GHOSH, Sutama. 2005. "We Are Not All the Same: The Differential Migration, Settlement Patterns, and Housing Trajectories of Indian Bengalis and Bangladeshis in Toronto," PhD thesis, York University.

GILL, Jagjeet.2007. Exploring Issues of Identity among Punjabi-Sikh Youth in Toronto. CERIS Working Paper

Series No. 53. Toronto: Joint Centre of Excellence for Research 2007 sin gle education on Immigration and Settlement - Toronto.

[Available at www.ceris.metropolis.net]

GLAVINIC, Mila L. 2005. "Developing an Online Community Practice: A Case Study of Professional Development Needs for ESL Practitioners Working with the Canadian Language $2005 \mathrm{sin}$ gle education Benchmarks," MA thesis, University of Toronto.

GRANT, Hugh and SWEETMAN, Arthur. 2004. "Introduction

to Economic and Urban Issues in Canadian Immigration Policy," $2004 \mathrm{~m}$ ultiple 2 economics Canadian Journal of Urban Research 13 (1), 1-24.

HAYAKAWA, Yukari. 2007. “Access to Professions: The Experience of Japanese Immigrants In Canada,” MRP, Immigration and Settlement Studies Program, Ryerson University.

HOWARD, Heather. 2005. "Dreamcatchers in the City: An Ethnohistory of Social Action, Gender, and Class in Native Community Production in Toronto," PhD thesis, University of Toronto.
1 NGO funder, 1 $2005 \mathrm{~m}$ ultiple sociology, 1 urban planning

2003 sin gle health sciences
$2007 \mathrm{~m}$ ultiple

2 gov (Canadian Heritage)

2005 sin gle geography
$2005 \mathrm{sin}$ gle anthropology 
HYMAN, Ilene; FORTE, Tonia; DU MONT, Janice; ROMANS, Sarah; and COHEN, Marsha. 2006. "Help- Seeking Rates for Intimate Partner Violence (IPV) among Canadian Immigrant $2006 \mathrm{~m}$ ultiple 5 health sciences Women," Health Care for Women International 27 (8), 682-694.

JENKINS, William M. 2005. "Deconstructing Diasporas:

Networks and Identities among the Irish in Buffalo and Toronto, 2005 sin gle geography 1870-1910," Immigrants and Minorities 23 (2, 3), 359-398.

KAMINSKY, Elizabeth. 2006. "The Evolution of Advocacy in the Ontario Immigrant Settlement Sector," MRP, Immigration 2006 sin gle ISS and Settlement Studies Program, Ryerson University.

KHAJA, Khadija. 2004. "Female Circumcision: Life Histories of Somali Women," [compares Somalis Muslim women in Salt 2004 sin gle social work Lake City and Toronto], PhD thesis, University of Utah.

KILBRIDE, Kenise Murphy. 2000. A Review of the Literature on the Human, Social, and Cultural Capital of Immigrant Children and Their Families with Implications for Teacher Education, CERIS Working Paper Series No. 13. Toronto: Joint 2000 sin gle education Centre of Excellence for Research on Immigration and Settlement - Toronto. [Available at www.ceris.metropolis.net]

KIM, Tae-Young. 2007. "Second Language Learning

Motivation from an Activity Theory Perspective:

Longitudinal Case Studies of Korean ESL Students and Recent 2007 sin gle education Immigrants in Toronto," $\mathrm{PhD}$ thesis, University of Toronto.

KUNZ, Jean Lock; MILAN, Anne; and SCHETAGNE, Sylvain. 2000. Unequal Access: A Canadian Profile of Racial Differences
in Education, Employment, and Income. Toronto: Canadian Race Relations Foundation.

KWAK, Kyunghwa and BERRY, John W. 2001. "Generational Differences in Acculturation among Asian Families in Canada: A Comparison of Vietnamese, Korean, and $2001 \mathrm{~m}$ ultiple 2 health sciences East-Indian Groups," International Journal of Psychology 36 (3), 152-162.

LAU, Chun K. 2004. "Moving Back and Forth Between Hong

Kong and Toronto: A Narrative Inquiry Into a Family’s Cultural 2004 sin gle education
and Educational Experiences," EdD thesis, University of Toronto.

LEUNG, Ho Hon.2000. Settlement Service Policies and

Settlement Issues among Chinese Canadian in Canada.

Toronto: Citizenship and Immigration Canada - OASIS. $2000 \sin$ gle gov [Available at www.ceris.metropolis.net] 
LO, Lucia; TEIXEIRA, Carlos; and TRUELOVE, Marie. 2002.

Cultural Resources, Ethnic Strategies, and Immigrant

Entrepreneurship: A Comparative Study of Five Immigrant

Groups in the Toronto CMA, CERIS Working Paper Series No. $2002 \mathrm{~m}$ ultiple 3 geography

21 [Caribbean community]. Toronto: Joint Centre of Excellence

for Research on Immigration and Settlement - Toronto.

[Available at www.ceris.metropolis.net]

MAHTANI, Minelle. 2000. "Mapping the Paradoxes of

Multiethnicity: Stories from Women of Multiethnicity in

Toronto, Canada," PhD thesis, University College, London.

2000 sin gle geography

MAITER, Sarah; TROCME, Nico; and GEORGE, Usha. 2000.

Building Bridges: The Collaborative Development of Culturally-

Appropriate Definitions of Child Abuse and Neglect for the

2000 multiple 3 social work

South Asian Community, report on a CERIS-funded research

project, 2000. [Available at www.ceris.metropolis.net]

MEHTA, Krishan. 2005. "Rethinking Immigrant Success: The

Case of Four South Asian Entrepreneurs in Toronto," MA thesis, 2005 sin gle unidentified

University of Toronto.

MENSAH, Joseph. 2002. Black Canadians: History,

Experiences, Social Conditions [Some Toronto references]. $2002 \mathrm{sin}$ gle social sciences

Halifax: Fernwood Publishing.

MENZIES, Peter M. 2005. "Orphans within Our Family:

Intergenerational Trauma and Homeless Aboriginal Men,"

[based on interviews with 16 homeless Aboriginal men in

2005 sin gle aboriginal studies

downtown Toronto], $\mathrm{PhD}$ thesis, University of Toronto.

MILLS, Beth H. 2002. "Family Land in Carriacou, Grenada and

Its Meaning within the Transnational Community: Heritage,

Identity, and Rooted Mobility," [did interviews in Brooklyn and 2002 sin gle anthropology

Toronto], $\mathrm{PhD}$ thesis, University of California at Davis.

MORTAZAVI, Mazyar. 2006. "Reconciling Change: The

Kensington Challenge," M Arch thesis, University of Waterloo.

MURDIE, Robert A. 2002. "The Housing Careers of Polish and

Somali Newcomers in Toronto's Rental Market,"

Housing Studies 17 (3), 423-443.

$2006 \mathrm{sin}$ gle architecture

NOH, Samuel and KASPAR, Violet. 2003. "Perceived

Discrimination and Depression: Moderating Effects of Coping,

Acculturation, and Ethnic Support," American Journal of Public

$2003 \mathrm{~m}$ ultiple

1 sociology, 1 health

Health 93 (2), 232-238.

sciences

NYERS, Peter. 2005. "The Regularization of Non-Status

Immigrants in Canada: Limits and Prospects," Canadian Review 2005 sin gle political science

of Social Policy 55, 109-114.

OGIORUMUA, Vera Eniso. 2001. "Nigerian Immigrant Youth

and the Toronto School System: A Challenge to the Students,"

MEd thesis, York University.

$2001 \mathrm{sin}$ gle education

OJIMA, Maki. 2004. “An Inquiry Into Concept Mapping as a

Form of Pre-Task Planning in Adult Japanese ESL

Learners' Essay Writing," MA thesis, University of Toronto.

OMIDVAR, Ratna and RICHMOND, Ted. 2003. Immigrant

Settlement and Social Inclusion in Canada. Toronto: The

2002 sin gle geography

Laidlaw Foundation.

2004 sin gle education

$2003 \mathrm{~m}$ ultiple $2 \mathrm{NGO}$ 
ONTARIO ADMINISTRATION OF SETTLEMENT AND

IMMIGRATION SERVICES. 2002. Putting The Pieces

Together Resource Catalogue II: Products Developed for Use in 2002 sin gle gov

Immigrant Settlement Programs Across Ontario. Toronto:

OASIS.

ONTARIO HUMAN RIGHTS COMMISSION. 2003. Paying

the Price: The Human Cost of Racial Profiling. Toronto: Ontario 2003 sin gle

Human Rights Commission.

PON, Gordon. 2004. "Anti-Racism Education in the

Cosmopolis: Reflection by Chinese Canadian Elites about $2004 \sin$ gle education

Race and Racism," PhD thesis, York University.

RAMSARRAN, Parbattie. 2006. "Mending the Double Rupture:

The Reconstruction of an Ethnic Identity and Distinct Ethnic

Community among Indo-Guyanese in the Greater Toronto

$2006 \mathrm{sin}$ gle sociology

Area," $\mathrm{PhD}$ thesis, York University.

RASILE, Teresa C. 2003. "The President Salvador Allende

School: A Case Study in the Education of Chilean

Refugee Children in Toronto," MA thesis, University of

$2003 \sin$ gle unidentified

Toronto.

REITZ, Jeffrey G. 2007. Immigrant Employment Success in

Canada, Part 1: Individual and Contextual Causes. Journal of

International Migration and Integration 8 (1), 11-36.

RENAUD, Jean; BÉGIN, Karine; FERREIRA, Virginie; and

ROSE, Damaris. 2006. "The Residential Mobility of

Newcomers to Canada: The First Months," Canadian Journal of

Urban Research 15 (2), 67-81.

independent statutory

body

RUPRECHT, Tony.. 2001. Toronto's Many Faces: A Guide to

the Media, Museums, Restaurants, Festivals, Monuments,

Prominent Citizens, and Shops of More Than 60 Cultural

$2001 \mathrm{sin}$ gle unidentified at all

Communities in the City, 3 ed. Kingston: Quarryrd Press.

SAKAMOTO, Mitsuyo. 2000. "Raising Bilingual and Trilingual

Children: Japanese Immigrant Parents' Child- Rearing

2000 sin gle education

Experiences," $\mathrm{PhD}$ thesis, University of Toronto.

2007 sin gle sociology

SALAFF, Janet W. and CHAN, Pearl. 2007. "Competing

Interests: Toronto's Chinese Immigrant Associations

and the Politics of Multiculturalism," Population, Space, and

$2007 \mathrm{~m}$ ultiple

1 sociology, 1 urban

$2006 \mathrm{~m}$ ultiple planning, and 2

unidentified

Place 13 (2), 125-140.

SHAHSIAH, Sara. 2005. "Identity, Identification, and

Racialization: Immigrant Youth in the Canadian Context," MRP, 2005 sin gle
Immigration and Settlement Studies Program, Ryerson

Immigration and Settlement Studies Program, Ryerson

ISS

University.

SHAUGHNESSY, Sarah C. 2004. "Cultural Differences in

Social Relevance: Does the Analytic/Holistic

Distinction Apply?," [compares Chinese and Western European 2004 sin gle unidentified

students at the $\mathrm{U}$ of T], MA thesis, University

of Toronto.

SIMICH, Laura. 2000. Towards a Greater Toronto Charter:

Implications for Immigrant Settlement. Toronto: The Maytree 2000 sin gle NGO

Foundation.

SOLOMON-HENRY, Gale. 2006. “African Indigenous

Knowledges and Education: Implications for Youth ofAfrican

Descent and Black-Focused Schools in Toronto," EdD thesis,

$2006 \mathrm{sin}$ gle education

University of Toronto. 
TARDIF, Christine Y. 2003. "Conflict and Adolescent Autonomy among Chinese-Canadian Immigrant Mother- Child Dyads: An Intracultural Study of the Influence of Acculturation

2003 sin gle health sciences Disparity," $\mathrm{PhD}$ thesis, University of Toronto.

TEIXEIRA, Jose Carlos. 2001. "Community Resources and Opportunities in Ethnic Economies: A Case Study of Portuguese
and Black Entrepreneurs in Toronto," Urban Studies $38(11)$, 2055-2078.

TEIXEIRA, Jose Carlos. 2007. Toronto's Little Portugal: A Neighbourhood in Transition, Research Bulletin No. 35. Toronto: Centre for Urban and Community Studies, University 2007 sin gle geography of Toronto.

TORBATI, Maryam. 2006. "Immigrant Entrepreneurship: A Case Study of Iranian Businesses in the Toronto CMA," MA 2006 sin gle geography thesis, York University.

TORCZYNER, James L. 2003. The Shaping of Toronto's Black Community: A Demographic Analysis of the Black Community in Toronto and Regions. Montreal: Toronto Black Communities 2003 sin gle demography Demographics Project, McGill Consortium for Ethnicity and Strategic Social Planning.

VANDE BERG, Travis. 2005. "ISKCON and Indians: Religion and Identity in North American Hinduism," [examines temples in Chicago and Toronto], $\mathrm{PhD}$ thesis, Loyola $2006 \mathrm{sin}$ gle sociology University Chicago.

WAN, Fung-Ling Mary. 2003. "Language, Social Networks, and Parenting in the Lived Experiences of Five Working-Class Chinese Immigrant Women in Toronto: An Ethnographic $2003 \mathrm{sin}$ gle sociology Study," PhD thesis, University of Toronto.

WANG, Lu and LO, Lucia. 2004. Chinese Immigrants in Canada: Their Changing Composition and Economic Performance, CERIS Working Paper Series No. 30. Toronto: Joint Centre of Excellence for Research on $2004 \mathrm{~m}$ ultiple 2 geography Immigration and Settlement - Toronto. [Available at www.ceris.metropolis.net]

WANG, Shuguang and TRUELOVE, Marie. 2003. "Evaluation of Settlement Service Programs for Newcomers in Ontario: A Geographical Perspective," Journal of International Migration $2003 \mathrm{~m}$ ultiple 2 geography and Integration 4 (4), 577-606.

WERNECK, Renata I. 2005. "Early Childhood Caries and Access to Dental Care in Portuguese-Speaking Immigrant Children Aged Up to 48 Months in the City of 2005 sin gle health sciences Toronto," M Sc thesis, University of Toronto. WOROTYNEC, Sonia (Zofia). 2005. "CHILD, INTERRUPTED: International Adoption and Canadian Immigration Policy," MRP, Immigration and Settlement Studies
Program, Ryerson University. WORTLEY, Scot and TANNER, Julian. 2005. "Inflammatory

Rhetoric? Baseless Accusations? Responding to Gabor's Critique of Racial Profiling Research in Canada," Canadian $2005 \mathrm{~m}$ ultiple 1 social sciences, 1 Journal of Criminology 47 (3): 581-609. 
WU, Fei. 2003. "Chinese Community and the Police: A Study of

Chinese People's Perception of the Police in

$2003 \sin$ gle social work

the City of Toronto," MSW thesis, University of Toronto.

XU, Shijing. 2006. "In Search of Home on Landscapes in

Transition: Narratives of Newcomer Families' Cross- Cultural

Schooling Experience," [examination of Bay Street Community

2006 sin gle education

YEE, June. 2001. Apprenticeship Opportunities and Barriers for

Immigrant Youth in the Greater Toronto Area, report on a

CERIS-funded research project, 2001. [Available at

$2001 \mathrm{sin}$ gle social work

www.ceris.metropolis.net]

YUEN, Elaine. 2005. "The Experience of Chinese Women and

School Councils in Toronto," MA thesis, University of Toronto.

$2005 \mathrm{sin}$ gle unidentified

ZINE, Jasmin. 2002. Living on the Ragged Edges: Absolute and

Hidden Homelessness among Latin Americans

and Muslims in West Central Toronto: Final Report. Toronto:

Equinox Research and Consulting Services for the

$2002 \mathrm{sin}$ gle sociology

Informal Housing Network Project. [Available at

www.ceris.metropolis.net] 